\title{
Reactive oxygen species in phagocytic leukocytes
}

\author{
John M. Robinson
}

Accepted: 5 June 2008 / Published online: 3 July 2008

(C) Springer-Verlag 2008

\begin{abstract}
Phagocytic leukocytes consume oxygen and generate reactive oxygen species in response to appropriate stimuli. The phagocyte NADPH oxidase, a multiprotein complex, existing in the dissociated state in resting cells becomes assembled into the functional oxidase complex upon stimulation and then generates superoxide anions. Biochemical aspects of the NADPH oxidase are briefly discussed in this review; however, the major focus relates to the contributions of various modes of microscopy to our understanding of the NADPH oxidase and the cell biology of phagocytic leukocytes.
\end{abstract}

Keywords NADPH oxidase - Respiratory burst · Phagocytosis · Neutrophils · Cytochemistry

\section{Introduction}

Phagocytic leukocytes, when appropriately stimulated, consume oxygen and produce superoxide $\left(\mathrm{O}_{2}^{-}\right)$in a process often referred to as the respiratory burst. Much of the work that has led to our current understanding of the regulatory events and the molecular organization underlying the respiratory burst is derived from studies of neutrophils, the

This paper is dedicated to the memory of late John A. Badwey, an insightful and creative scientist, with whom the author enjoyed a fruitful collaboration studying neutrophil biology that spanned over 20 years.

J. M. Robinson $(\bowtie)$

Department of Physiology and Cell Biology,

Ohio State University, Columbus, $\mathrm{OH} 43210$, USA

e-mail: robinson.21@osu.edu most abundant of the phagocytic cells in blood. Therefore, this review will likewise focus on the neutrophil.

The respiratory burst is mediated by the NADPH-oxidase complex, a multicomponent system that is rapidly assembled following activation of neutrophils. As we have discussed previously, the neutrophil NADPH oxidase produces $\mathrm{O}_{2}^{-}$and hydrogen peroxide $\left(\mathrm{H}_{2} \mathrm{O}_{2}\right)$ following activation (Robinson et al. 2004). The NADPH oxidase catalyzes the production of $\mathrm{O}_{2}^{-}$:

$\mathrm{NADPH}+2 \mathrm{O}_{2} \rightarrow \mathrm{NADP}^{+}+2 \mathrm{O}_{2}^{-}+\mathrm{H}^{+}$

A dismutation reaction occurs with $\mathrm{O}_{2}^{-}$to produce peroxide:

$\mathrm{O}_{2}^{-}+\mathrm{O}_{2}^{-}+2 \mathrm{H}^{+} \rightarrow \mathrm{H}_{2} \mathrm{O}_{2}+\mathrm{O}_{2}$

Both $\mathrm{H}_{2} \mathrm{O}_{2}$ and $\mathrm{O}_{2}^{-}$are components of the oxygen-dependent, antimicrobial system of phagocytic leukocytes (e.g., Robinson and Badwey 1995).

In part, the cytotoxic effects of $\mathrm{O}_{2}^{-}$and $\mathrm{H}_{2} \mathrm{O}_{2}$ relate to their ability to react with products of other microbicidal systems in these cells to generate additional reactive oxygen species (ROS) [e.g., hydroxyl radical $(\mathrm{OH} \cdot)$, singlet oxygen $\left({ }^{1} \mathrm{O}_{2}\right)$, ozone $\left.\left(\mathrm{O}_{3}\right)\right]$. Superoxide can react with either hypochlorous acid $(\mathrm{HOCl})$ or nitric oxide (NO-) to produce $\mathrm{OH}$. (Beckman et al. 1990; Ramos et al. 1992).

$$
\begin{aligned}
& \mathrm{O}_{2}^{-}+\mathrm{HOCl} \rightarrow \mathrm{OH} \cdot+\mathrm{O}_{2}+\mathrm{Cl}^{-} \\
& \mathrm{O}_{2}^{-}+\mathrm{NO} \cdot+\mathrm{H}^{+} \rightarrow \mathrm{OH} \cdot+\mathrm{NO}_{2}
\end{aligned}
$$

Hypochlorous acid and nitric oxide are produced in phagocytic leukocytes by myeloperoxidase and nitric oxide synthase, respectively (Harrison and Schultz 1976; Xie et al. 1992). Singlet oxygen can form by nonenzymatic dismutation of superoxide (Corey et al. 1987). Additionally, hydrogen peroxide and the 
deprotonated form of hypochlorous acid $\left(\mathrm{OCl}^{-}\right)$can react to form ${ }^{1} \mathrm{O}_{2}$ (Steinbeck et al. 1992).

$\mathrm{H}_{2} \mathrm{O}_{2}+2 \mathrm{OCl}^{-} \rightarrow{ }^{1} \mathrm{O}_{2}+\mathrm{H}_{2} \mathrm{O}_{2}+2 \mathrm{Cl}^{-}$

More recently it was shown that ${ }^{1} \mathrm{O}_{2}$ and $\mathrm{H}_{2} \mathrm{O}_{2}$ react in an antibody catalyzed reaction to form ozone and that ozone and $\mathrm{H}_{2} \mathrm{O}_{2}$ can react to form hydroxyl radical and superoxide (Wentworth et al. 2002).

$2^{1} \mathrm{O}_{2}+\mathrm{H}_{2} \mathrm{O} \rightarrow \mathrm{H}_{2} \mathrm{O}_{2}+\mathrm{O}_{3}$
$\mathrm{O}_{3}+\mathrm{H}_{2} \mathrm{O}_{2} \rightarrow \mathrm{OH} \cdot+\mathrm{O}_{2}^{-}+\mathrm{O}_{2}+\mathrm{H}^{+}$

\section{The NADPH oxidase}

Physiological and biochemical changes associated with leukocyte phagocytosis were noted some time ago (Baldridge and Gerard 1933; Sbarra and Karnovsky 1959; Iyer et al. 1961). It was subsequently shown that superoxide is a product of the respiratory burst and that superoxide production is defective in neutrophils from patients with the genetic disease chronic granulomatous disease (CGD) (Babior et al. 1973; Curnutte et al. 1974). However, a fuller understanding of the underlying mechanisms associated with the respiratory burst had to await a number of methodological and technological advances. Neutrophils from CGD patients are unable to generate normal amounts of $\mathrm{O}_{2}^{-}$ owing to the loss of components of the NADPH-oxidase complex (reviewed in Segal et al. 2000; Heyworth et al. 2003; Malech and Hickstein 2007).

Regulation of the activation of the NADPH oxidase in neutrophils is exquisite since the oxidase is dormant in resting cells but is rapidly activated following appropriate stimulation of these cells. Due to the toxicity of its products, it is not surprising that the NADPH oxidase is highly regulated and limited in its sites of action. Physiological stimuli capable of activating the neutrophil oxidase include phagocytizable particles such as bacteria and yeast, certain molecules that induce chemotaxis in these cells, certain bioactive lipids, and antibodies. The chemotatic peptides, such as $f$-Met-Leu-Phe, have served as models for the study of receptor-ligand mediated activation of the NADPH oxidase. Other "non-physiological" agents can also activate the oxidase and have been important in understanding the regulation of the phagocyte NADPH oxidase. This latter group of compounds includes certain phorbol esters, fatty acids, and retinoids as well as sodium fluoride. The time course of activation of the oxidase and the amounts of reactive oxygen species produced varies depending on the agent used to stimulate cells and activate the oxidase. The rapid activation of the oxidase and the response of neutrophils to agonists can be appreciated by comparing the kinetics of the production

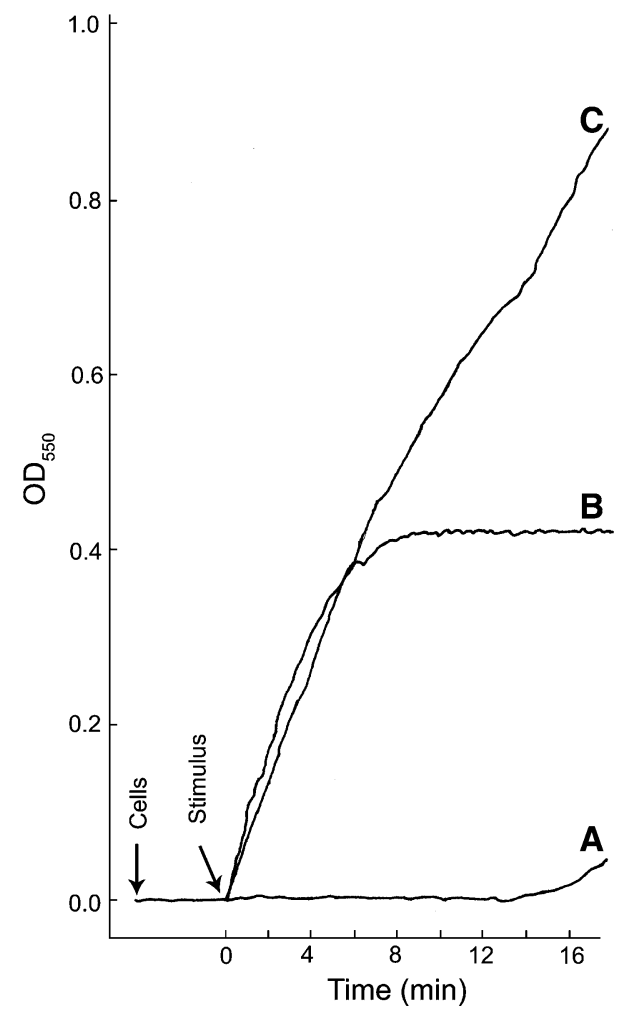

Fig. 1 The levels of $\mathrm{O}_{2}^{-}$produced and the rate at which it is produced can vary depending upon the stimulus. Real-time kinetics of $\mathrm{O}_{2}^{-}$production by thioglycolate-elicited guinea pig neutrophils stimulated in three different ways is shown; the cytochrome c reduction spectrophotometric assay was employed. Representative curves of cells stimulated with either $(A) \mathrm{NaF}(12.5 \mathrm{mM})$ plus $\mathrm{AlCl}_{3}(100 \mu \mathrm{M}),(B)$ the chemotatic peptide $f$-Met-Leu-Phe $\left(10^{-7} \mathrm{M}\right)$, or $(C)$ a combination of $f$-Met-Leu-Phe and $\mathrm{NaF}$ plus $\mathrm{AlCl}_{3}$ at the same concentrations used in curves $A$ and $B$. Cells $\left(1 \times 10^{6}\right)$ were added and allowed to equilibrate at $37^{\circ} \mathrm{C}$ for $3 \mathrm{~min}$ before addition of the stimulus; during that time the resting cells did not generate $\mathrm{O}_{2}^{-}$. Following the equilibration period, a stimulus was added (arrow). With $\mathrm{NaF}$ plus $\mathrm{AlCl}_{3}$ there was a long lag period prior to the release of modest amounts of $\mathrm{O}_{2}^{-}$(curve $A$ ). This lag period is likely due to the slow entry of the stimulus into the cells. The lag period was eliminated when cells were permeabilized by electroporation in the presence of $\mathrm{NaF}$ plus $\mathrm{AlCl}_{3}$ (Hartfield and Robinson 1990). When cells were stimulated with the chemotatic peptide, production of $\mathrm{O}_{2}^{-}$was essentially instantaneous and was largely shut down by $5 \mathrm{~min}$ post stimulation (curve $B$ ). When cells were stimulated by a combination of $f$-Met-Leu-Phe and NaF plus $\mathrm{AlCl}_{3}$, at the same concentrations used in curves $A$ and $B$, the initial rate of $\mathrm{O}_{2}^{-}$production was essentially the same as that for the chemotatic peptide alone; however, the shut off of the $f$-MetLeu-Phe stimulated $\mathrm{O}_{2}^{-}$was abrogated and the cells continued to produce $\mathrm{O}_{2}^{-}$at a high rate throughout the course of the incubation period. This experiment shows that: (1) resting neutrophils in suspension do not generate $\mathrm{O}_{2}^{-}$; (2) activation of the NADPH oxidase and the production of $\mathrm{O}_{2}^{-}$can be very rapid in intact neutrophils; and (3) different stimulatory conditions can lead to different levels of $\mathrm{O}_{2}^{-}$production and the kinetics of $\mathrm{O}_{2}^{-}$production vary with different stimulatory conditions. The continuous spectrophotometric assay for $\mathrm{O}_{2}^{-}$production was as we have described previously (Robinson et al. 1987) 
and release of superoxide from neutrophils in response to different stimulatory agents (Fig. 1) (Badwey et al. 1980). The rate of $\mathrm{O}_{2}^{-}$released from neutrophils in response to a variety of different agonists has been summarized (Robinson and Badwey 1995). An overview of the various methods used to measure reactive oxygen species and limitations associated with these methods has been presented (Tarpey et al. 2004).

There are several excellent reviews describing the components of the NADPH oxidase and the assembly of these components into the multiprotein complex capable of producing superoxide (Lambeth 2000; Babior et al. 2002; Vignais, 2002; Bokoch and Knaus 2003; Roos et al. 2003; Babior 2004; Cross and Segal 2004; Nauseef 2004; Groemping and Rittinger 2005; Matute et al. 2005; Sheppard et al. 2005; Dagher and Pick 2007; Nauseef 2007). Therefore a detailed analysis of this system will not be presented herein; instead, a distillation of the major features of the oxidase will be given. As is the case for most aspects of cell function, location is a key factor. This is certainly the case for the NADPH oxidase. Indeed, separation of different components of the oxidase in specific locations within the cell account for its dormancy in unstimulated cells. This is important since products of the oxidase are highly reactive and can lead to cell and tissue damage. Thus activation of the oxidase should occur only when necessary. It is only after appropriate stimulation that all of the components of the oxidase come together in a coordinated manner that this complex multicomponent molecular system is functional in intact cells (see below).

The so-called cell-free system in which homogenized neutrophils were subjected to ultracentrifugation to generate cytosol and membrane fractions have been important in sorting out the various components of the NADPH oxidase (Bromberg and Pick 1984; Heyneman and Vercauteren 1984; Curnutte 1985; McPhail et al. 1985). With this approach in hand, investigators could take membranes from one source and cytosol from another source and mix them together and assay for $\mathrm{O}_{2}^{-}$production [reviewed in Dagher and Pick 2007]. For example, membranes from normal neutrophils and cytosol from neutrophils from patients with chronic granulomatous disease (CGD) could be mixed, and vice versa. In addition to this genetic approach, recombinant forms of components of the oxidase complex, mutated forms of these proteins, chimeric proteins, and synthetic peptides have also been used in the cell-free system to analyze the NADPH oxidase (Dagher and Pick 2007). A large number of experiments have been carried out by several groups using a variety of approaches to study the NADPH oxidase in cell-free preparations. Taken together, these data have been crucial in leading to our current understanding of the components, their assembly, and regulation of the phagocyte NADPH oxidase.

The current model for the NADPH oxidase has the catalytic component, flavocytochrome $b_{588}$, located in the membrane. This heterodimeric flavocytochrome is composed of the proteins gp91 $1^{\text {phox }}$ and $\mathrm{p} 22^{\text {phox }}$ (Segal and Jones 1978; Dinauer et al. 1987; Parkos et al. 1988). The other components of the oxidase complex are in the cytoplasm. It is only after cell stimulation that the cytoplasmic components migrate to the membrane and associate with the gp91 $1^{\text {phox }}$ and $\mathrm{p} 22^{\text {phox }}$ complex. The cytosolic components of the oxidase consist of the proteins $\mathrm{p} 67^{\text {phox }}, \mathrm{p} 47^{\text {phox }}$, and $\mathrm{p} 40^{\text {phox }}$, which appear to exist as a complex awaiting mobilization to join the cytochrome $b_{558}$ upon cell stimulation (Wientjes et al. 1993, 1996; Zhan et al. 1998; Lapouge et al. 2002). An additional component of the NADPH oxidase is the GTP-bound form of Rac (Quinn et al. 1993; Abo et al. 1994; Bokoch and Diebold 2002). Until cell activation, Rac exists in association with RhoGDI in the GDP-bound form; upon cell stimulation, it dissociates from RhoGDI, exchanges GDP for GTP, and binds the NADPH oxidase (Bokoch et al. 1994; Kreck et al. 1996). As noted earlier, there are several excellent reviews covering the composition and assembly of phagocyte NADPH oxidase that have appeared since the turn of the century and the interested reader is referred to those publications. The present review will focus on the role microscopy has played in our understanding of the phagocyte NADPH oxidase.

\section{Microscopy in the study of the respiratory burst}

The tetrazolium method: detection of superoxide

Early microscopy studies of the respiratory burst in neutrophils relied on the dye nitroblue tetrazolium (NBT). Indeed, NBT was used to diagnose the absence of the respiratory burst in neutrophils from CGD patients (Nathan et al. 1969). The so-called NBT test predated the discovery that CGD neutrophils were unable to generate $\mathrm{O}_{2}^{-}$(Curnutte et al. 1974). The chemical basis of the NBT test has been presented elsewhere and will not be discussed herein (Auclair and Voisin 1985). The NBT reaction was adapted for electron microscopy but it was noted that the diformazan reaction product lacked sufficient electron density to be useful in this application (Briggs et al. 1975a). The tetrazolium 3-[4,5-dimethylthiazol-2-yl]-2,5-diphenyltetrazolium has also been used to monitor the respiratory burst (Pruett and Loftis 1990; Oez et al. 1993).

A quantitative video-microscopy assay using NBT was used to show heterogeneity in $\mathrm{O}_{2}^{-}$production among 
individual cells (DiGregorio et al. 1991). Other studies, using an end-point assay have also provided quantitative data for NBT reduction by activated leukocytes (e.g., Champelovier et al. 1993). A live cell imaging assay in which cytosolic $\mathrm{Ca}^{2+}$ was measured with the fluorescence probe Fura- 2 and $\mathrm{O}_{2}^{-}$production was detected with NBT, was developed. When neutrophils were stimulated with a chemotactic peptide, localized production of $\mathrm{O}_{2}^{-}$correlated with the location of a cytosolic "calcium cloud" (Davies et al. 1991). We have shown that the diformazan deposits in activated neutrophils can be monitored by laser scanning confocal microscopy using the reflectance mode (Robinson and Batten 1989; Robinson and Badwey 1995) (see Figs. 2, 3).

$\mathrm{H}_{2} \mathrm{O}_{2}$ detection in phagosomes with diaminobenzidine

The presence of $\mathrm{H}_{2} \mathrm{O}_{2}$ within neutrophil phagosomes was initially inferred from the cytochemical experiments of Briggs et al. (1975a). Myeloperoxidase (MPO), present in azurophil granules of neutrophils, is delivered to the phagosome by fusion of azurophil granules with phagosomes. Myeloperoxidase utilizes $\mathrm{H}_{2} \mathrm{O}_{2}$ in the generation of hypochlorous acid, a potent microbicidal agent, in the
Fig. 2 Cytochemical detection of sites of stimulated $\mathrm{O}_{2}^{-}$ generation with the NBT reaction and laser scanning confocal microscopy. A single neutrophil was allowed to adhere to a glass cover slip and was subsequently stimulated with $4 \beta$-phorbol 12-myristate acetate in the presence of NBT is shown. The cell was then optically sectioned and viewed by transmitted light $(\mathbf{a}-\mathbf{f})$ and by confocal laser scanning microscopy in the reflectance mode $\left(\mathbf{a}^{\prime}-\mathbf{f}^{\prime}\right)$. The non-confocal transmitted light images go from the substratum region (a) toward the apical portion of the cell (f). The reflectance images represent confocal sections corresponding to these different focal planes in the transmitted light images. Reaction product is present over the entire cell: however, there is heterogeneity in its distribution. Bar: $10 \mu \mathrm{m}$. Reprinted from Robinson and Badwey 1995
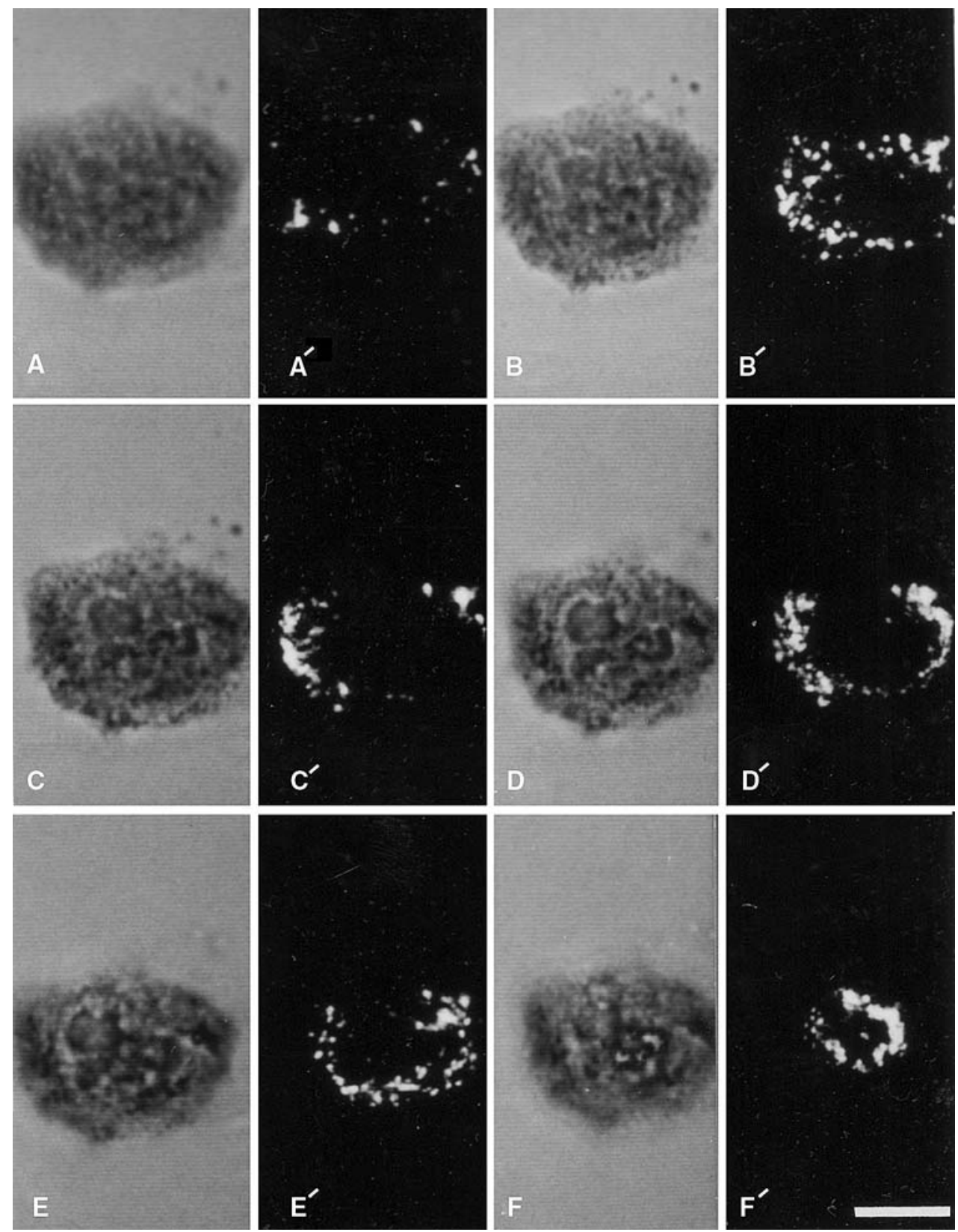

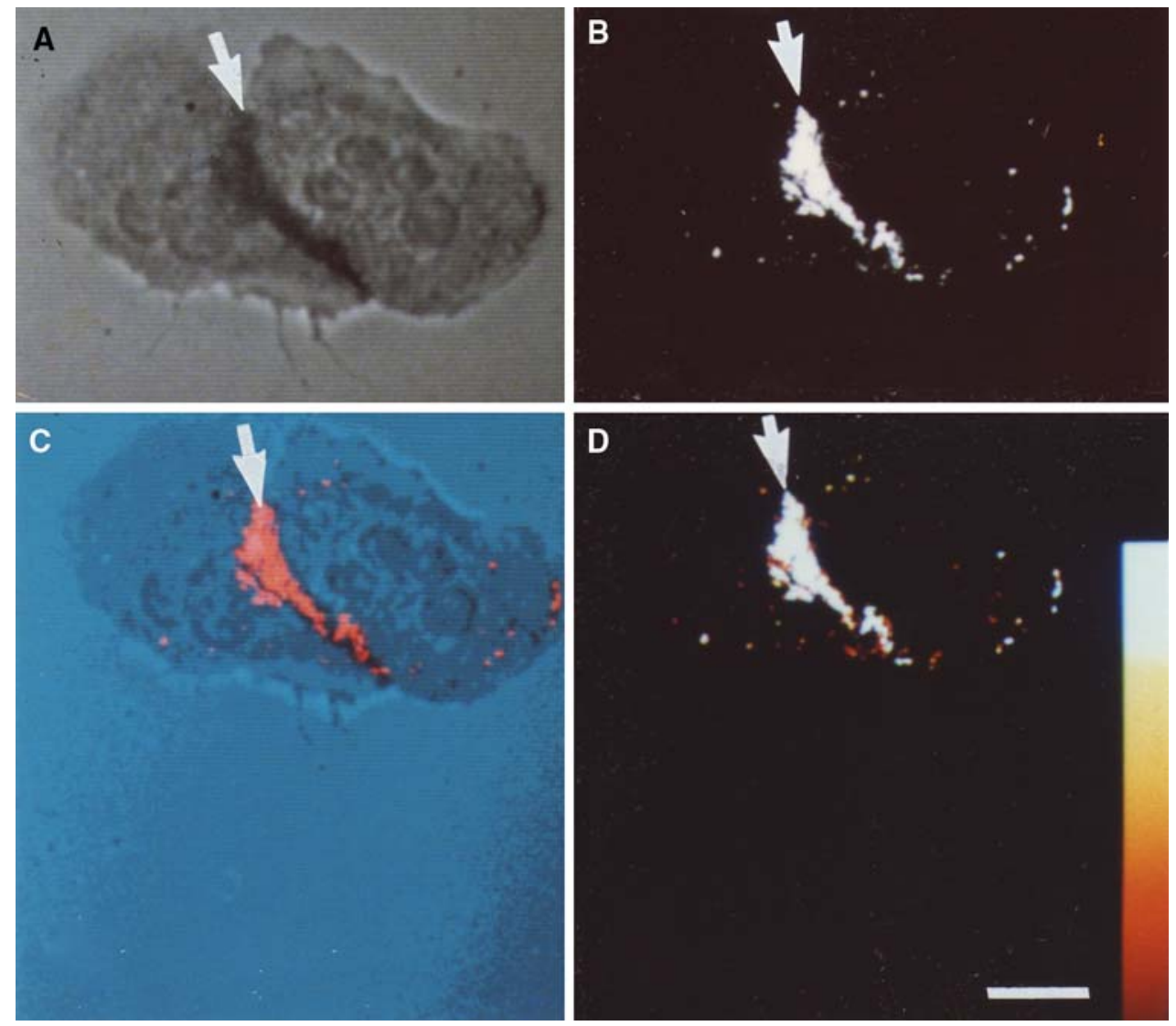

Fig. 3 Cytochemical detection of NBT-derived diformazan reaction product by reflected-light laser scanning confocal microscopy. Two neutrophils that were incubated with NBT in the absence of exogenous stimulating agents are shown. a Cells were viewed by non-confocal transmitted light. b The same cells were imaged by laser scanning confocal microscopy in the reflectance mode. The adherent neutrophils have a region of cell-cell contact. The reaction product, indicative of $\mathrm{O}_{2}^{-}$production, is detected in both the transmitted light image and the confocal reflectance image (arrows). c The co-

phagosome (Klebanoff 1970). The activity of MPO in the phagosome of intact neutrophils was detected with 3,3'diaminobenzidine (DAB). Deposits of reduced DAB in the phagosome strongly suggested that endogenous $\mathrm{H}_{2} \mathrm{O}_{2}$ was produced within the phagosome since exogenous $\mathrm{H}_{2} \mathrm{O}_{2}$ was not added to the cytochemical medium (Briggs et al. 1975a). Other DAB-based cytochemical methods for the localization of ROS have been developed (see below). The presence of MPO in the phagosome is important for the production of the full complement of microbicidal agents. The demonstration of MPO delivery to neutrophil phagosomes at the electron microscope level is shown (Fig. 4).

Detection of hydrogen peroxide with cerium

Hydrogen peroxide, produced by the rapid dismutation of superoxide, was initially detected at the ultrastructural localization of the transmitted light image and the confocal reflectance image is the pseudocolor merge of the two images; the reaction product is indicated by the arrow. $\mathbf{d}$ A color wedge has been inserted to estimate the intensity of the reflectance signal. Note that the diformazan reaction product is almost entirely restricted to the area of cell-cell contact, indicating the lack of a global signal transduction cascade leading to the generation of $\mathrm{O}_{2}^{-}$over the entirety of the cells. Bar: $10 \mu \mathrm{m}$. Reprinted from Robinson and Badwey 1995

level using a cerium-based cytochemical reaction (Briggs et al. 1975b). The cerium-based reaction proceeds as follows:

$$
\begin{aligned}
& \mathrm{NADPH}+2 \mathrm{O}_{2} \rightarrow \mathrm{NADP}^{+}+\mathrm{H}^{+}+2 \mathrm{O}_{2}^{-} \\
& 2 \mathrm{O}_{2}^{-}+2 \mathrm{H}^{+} \rightarrow \mathrm{H}_{2} \mathrm{O}_{2}+\mathrm{O}_{2} \\
& \mathrm{H}_{2} \mathrm{O}_{2}+\mathrm{CeCl}_{3}+3 \mathrm{OH}^{-} \rightarrow \mathrm{Ce}(\mathrm{OH})_{2} \mathrm{OOH}+\mathrm{H}_{2} \mathrm{O}+3 \mathrm{Cl}^{-}
\end{aligned}
$$

In this reaction, sequence endogenous phagocyte NADPH is utilized by the NADPH oxidase to generate $\mathrm{O}_{2}^{-}$. The $\mathrm{O}_{2}^{-}$ subsequently undergoes dismutation to form $\mathrm{H}_{2} \mathrm{O}_{2}$ which, in turn, reacts with cerium to form cerium perhydroxide, an electron dense product detectable in the electron microscope. Cerium perhydoxide is a fine, non-crystalline, electron-dense reaction product that generally forms with low background. Thus the cerium reaction is ideal for electron microscopy. However, the cerium perhydroxide reaction product was not initially considered useful for 


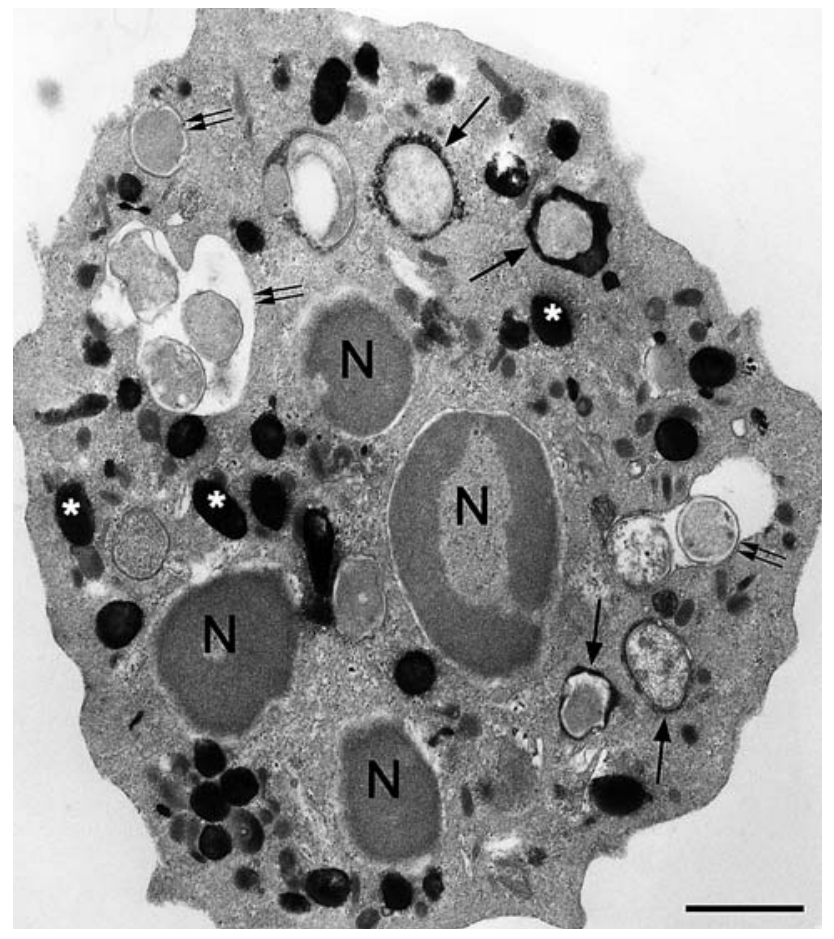

Fig. 4 Electron micrograph of a human neutrophil that has ingested $E$. coli minicells; the neutrophil was subsequently reacted for the cytochemical detection of MPO activity using the DAB method with exogenous $\mathrm{H}_{2} \mathrm{O}_{2}$. Black electron dense deposits are present in intracellular granules, the azurophil granules (asterisks), and within a population of phagosomes (arrows). Under these incubation conditions, there were some phagosomes that had not yet acquired MPO (double arrows). The cytochemical reaction for the detection of MPO activity following ingestion of minicells was carried out as we have described (Fox et al. 1987). Bar: $1 \mu \mathrm{m}$

bright-field optical microscopy. This problem was overcome as cerium perhydroxide could be converted to other products visible by bright-field microscopy (Zimmerman and Halbhuber 1985; Okada et al. 1987; Angermüller and Fahimi 1988; Halbhuber et al. 1988). It was subsequently found that the cerium perhydroxide reaction product can be detected directly, without conversion to another product, using the reflectance mode of the laser scanning confocal microscope (Robinson and Batten 1990). This latter method allows for direct visualization of the cerium reaction product and permits precise localization by means of confocal optical sectioning and collection of three-dimensional data sets. Cerium has proven to be a versatile tool for enzyme cytochemistry since it can also be used in the detection of several phosphatases and has several advantages over older methods for detection of these enzymes (Robinson and Karnovsky 1983a, b). The use of cerium in oxidase and phosphatase enzyme cytochemistry has been reviewed (Van Noorden and Fredericks 1993; Halbhuber et al. 1994; Karnovsky 1994).

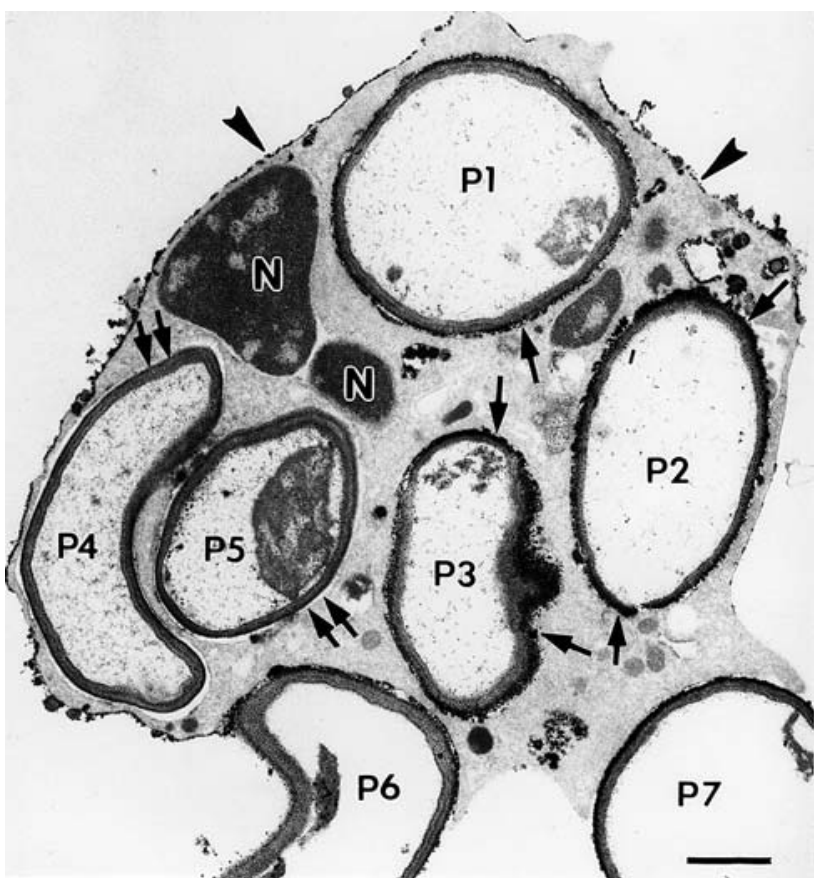

Fig. 5 Electron micrograph illustrating the cytochemical detection of $\mathrm{H}_{2} \mathrm{O}_{2}$ with the cerium method in a neutrophil that was stimulated by phagocytosis. This thin-section electron micrograph is of a cell that had phagocytized zymozan particles (yeast cell walls) and was then incubated for cytochemistry as described previously (Briggs et al. 1975b). Electron-dense reaction product is present on portions of the cell surface (arrowheads) and in some phagosomes. In this cell profile, five zymozan particles appear to be within phagosomes (P1-5), while two additional particles are bound to the cell surface, but are incompletely internalized $(P 6-7)$. Note that some particles $(P 1-3)$ have reaction product surrounding the luminal aspect of the phagosomes (arrows), while other particles (P4-5) lack reaction product in the phagosomes (double arrows). Portions of the nucleus $(N)$ are evident. These results indicate an asymmetry in the spatial and/or temporal delivery of $\mathrm{H}_{2} \mathrm{O}_{2}$ to phagosomes. Bar: $1 \mu \mathrm{m}$. Reprinted from Robinson and Badwey 1995

When neutrophils are incubated with phagocytizable particles, such as yeast cell walls, in the cerium-based cytochemical medium developed by Briggs et al. (1975b), the reaction product is evident within phagosomes and at the cell surface. These results were confirmed in other studies (Badwey et al. 1980; Ohno et al. 1982). There are also deposits of reaction product in vesicle-like structures in the cytoplasm (see more below). We have noted that typically phagosomes can vary with regard to the apparent amount of reaction product per phagosome with some phagosomes lacking reaction product altogether suggesting an asymmetric delivery of $\mathrm{H}_{2} \mathrm{O}_{2}$ to phagosomes (Fig. 5). Similar asymmetry in the delivery of ROS to phagosomes was obtained in living cells by Soret band transmitted light microscopy of neutrophils that phagocytized antibodycoated red blood cells (Petty et al. 1992). Griffiths (2004) proposes that heterogeneity in phagosomes within the same 
cell is the norm. The asymmetric delivery of ROS was also noted in neutrophils attached to aggregated $\mathrm{IgG}$ associated with glomerular basement membranes; in this case the reaction product, indicative of $\mathrm{H}_{2} \mathrm{O}_{2}$ production, was on the side of the neutrophil attached to the non-phagocytizable basement membrane (Vissers et al. 1985). The asymmetric generation of ROS has been observed by fluorescence microscopy (see more below) in polarized neutrophils (i.e., crawling over a substratum) (Kindzelskii and Petty 2002). We also observed polarized distribution of cerium perhydroxide, indicative of $\mathrm{H}_{2} \mathrm{O}_{2}$ production, in crawling cells (Heyworth et al. 1997). This appears be similar to the situation reported by Kindzelskii and Petty (2002) who used fluorescence microscopy. Another example of the asymmetric generation of ROS was previously shown herein using NBT as the detection reagent; in this case, $\mathrm{O}_{2}^{-}$was detected where two polarized cells made contact (see Fig. 3). These findings, enabled by microscopy, indicate the complexity of the regulation of production of ROS by phagocytic leukocytes and raise a number of intriguing questions related to the cell biology and biochemistry of the respiratory burst. Such asymmetric and/or polarized generation of ROS may have important implications in pathophysiology.

It is generally considered that the activated NADPH oxidase is associated with the plasma membrane or its derivative the phagosome (e.g., Nauseef 2004). However, there are several findings that suggest that there may be a separate intracellular pool of NADPH oxidase activity (Lundqvist et al. 1996; Kobayashi et al. 1998; LundqvistGustafsson and Bengtsson 1999; Vaissiere et al. 1999; Karlsson et al. 2000; Karlsson and Dahlgren 2002; Brown et al. 2003; Ambruso et al. 2004). There are often small vesicle-like structures containing cerium perhydroxide indicative of the production of $\mathrm{H}_{2} \mathrm{O}_{2}$ in cells that have phagocytized particles (Fig. 6). These structures can vary in number from one thin section to another in conventional electron microscopy such that some sections have numerous cerium perhydroxide-containing vesicles and other sections have few or even none of the positive vesicles. A detailed analysis of serially sectioned neutrophils that had internalized particles and in which the localization of $\mathrm{H}_{2} \mathrm{O}_{2}$ had also been carried out, would be required to address this question adequately and to understand further this intracellular pool of NADPH oxidase in neutrophils following phagocytosis. Insofar as the author knows, such an analysis has not been conducted. The exact nature of these vesicles containing reaction product needs further investigation to determine if they are intracellular in origin or whether they are derived from the plasma membrane since it has been reported that a burst of pinocytosis accompanies phagocytosis (Botelho et al. 2002). However, even if these

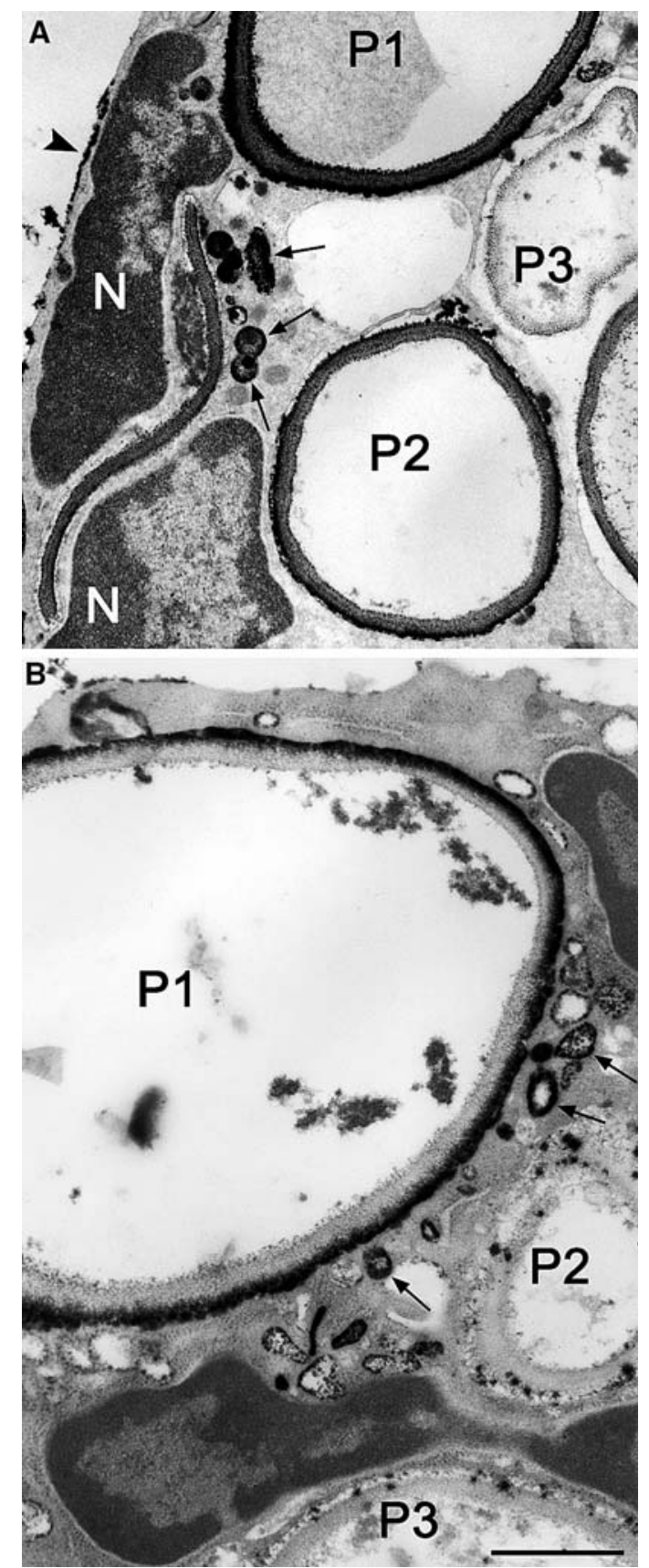

Fig. 6 Electron micrographs of portions of two different neutrophils that ingested zymosan particles; sites of $\mathrm{H}_{2} \mathrm{O}_{2}$ generation were detected with the cerium-based cytochemical reaction. a A portion of a cell is shown in which phagosomes show a spectrum of responses: $P 1$, heavy reaction product; $P 2$, moderate reaction product; $P 3$, little reaction product. There are several small vesicular structures containing reaction product in the periphagosome region (arrows) suggesting intracellular sites of $\mathrm{H}_{2} \mathrm{O}_{2}$. Patches of reaction product are at the cell surface (arrowhead). Portions of the nucleus $(N)$ are visible. b A portion of a cell is shown in which phagosomes show different responses: $P 1$, heavy reaction product; $P 2$ and $P 3$, little reaction product. There are several small vesicular structures containing reaction product in the periphagosome region (arrows) suggesting intracellular sites of $\mathrm{H}_{2} \mathrm{O}_{2}$. Patches of reaction product are at the cell surface (arrowhead). Portions of the nucleus $(N)$ are visible. Bars: $1 \mu \mathrm{m}$ 
vesicles containing reaction product showing $\mathrm{H}_{2} \mathrm{O}_{2}$ production are pinocytotic in origin, there remains the question of how (and when) are the cytosolic components of the oxidase directed to these sites.

\section{$\mathrm{O}_{2}^{-}$detection with $\mathrm{DAB}-\mathrm{Mn}^{2+}$}

A cytochemical method for the ultrastructural localization of $\mathrm{O}_{2}^{-}$was developed; the cytochemical medium contains DAB-Mn ${ }^{2+}$ as the key components (Briggs et al. 1986). Subsequent study showed that this method was specific for $\mathrm{O}_{2}^{-}$and was not responsive to ${ }^{1} \mathrm{O}_{2}$ (Steinbeck et al. 1993). A modification of this methodology was used to localize sites of superoxide production in rat endothelium in situ (Babbs et al. 1991a, b). The DAB-Mn ${ }^{2+}$ procedure along with modification of this DAB method has been reviewed (Babbs 1994). The DAB- $\mathrm{Mn}^{2+}$ method was used to analyze intracellular sites of $\mathrm{O}_{2}^{-}$in phorbol ester-activated neutrophils (Kobayashi et al. 1998). This latter study generated interest since it identified intracellular sites of $\mathrm{O}_{2}^{-}$production as being distinct from plasma membrane derived vesicles. Two alternative explanations could be posited for this observation. One explanation is that bona fide sites of NADPH oxidase assembly and activation occur on certain intracellular compartments; the second explanation is that the cytochemical reaction occurs in vesicles that were internalized and are in reality derived from the plasma membrane and do not represent an intracellular pool of NADPH oxidase. To address the source of the $\mathrm{O}_{2}^{-}$positive compartments, Kobayashi and colleagues used native and cationic ferritin in conjunction with $\mathrm{O}_{2}^{-}$localization. Ferritin was used to mark plasma membranederived endocytic vesicles. Sites of $\mathrm{O}_{2}^{-}$production were distinct from ferritin-positive vesicles, indicating that these sites of $\mathrm{O}_{2}^{-}$production were not derived from the plasma membrane. However, the $\mathrm{O}_{2}^{-}$- positive compartments and the ferritin-positive compartments did fuse and their contents mix at later times. This illustrates the complex patterns of intracellular membrane trafficking in activated neutrophils. The Kobayashi study also combined $\mathrm{O}_{2}^{-}$ cytochemistry and cerium-based cytochemistry for the detection of alkaline phosphatase. This was possible since the electron-dense reaction products generated with these two cytochemical reactions were distinct in their morphology. It was found that these two cytochemical reactions occurred in the same compartment. Moreover, the kinetics of phorbol ester-induced $\mathrm{O}_{2}^{-}$generation (as measured biochemically) and the up regulation of alkaline phosphatase activity to the cell surface (as measured biochemically) occurred with a similar time course. This further supports the contention that intracellular generation of $\mathrm{O}_{2}^{-}$is associated with the alkaline phosphatase-positive compartment. Previous work had shown that alkaline phosphatase was unregulated to the cell surface in response to chemoattractants (Borregaard et al. 1987). Subsequently it was shown that alkaline phosphatase resides in unique rod-shaped structures that are in lower abundance than azurophil or specific granules and in response to chemoattractants these structures appeared to fuse into longer tubular compartments that also fused with the plasma membrane (Kobayashi and Robinson 1991; Robinson et al. 1999).

Immunocytochemical localization of components of the NADPH oxidase

Immunocytochemical localization of NADPH oxidase components has been important in understanding the assembly of the NADPH oxidase. The rates of ROS generation by neutrophils during phagocytosis, with two different types of particles, were measured biochemically and compared to the kinetics of the association of cytochrome $\mathrm{b}_{558}$ and $\mathrm{p} 47^{\text {phox }}$ and $\mathrm{p} 67^{\text {phox }}$ with phagosomes as determined by immunofluorescence microscopy (DeLeo et al. 1999). It was found that cytochromes $b_{558}$ and $p 47^{\text {phox }}$ and $\mathrm{p} 67^{\text {phox }}$ are associated with phagosomes and that $\mathrm{p} 47^{\text {phox }}$ and $\mathrm{p} 67^{\text {phox }}$ subsequently dissociated from the phagosome; this later event correlated with the end of the oxidase activity. This same group, using immunofluorescence microscopy, showed in neutrophils from patients with X-linked CGD that $\mathrm{p} 47^{\text {phox }}$ and $\mathrm{p} 67^{\text {phox }}$ accumulated in the periphagosomal region but did not remain when phagocytosis was completed (Allen et al. 1999). In contrast, phagocytosis in normal neutrophils was accompanied by a more stable assembly of $\mathrm{p} 47^{\text {phox }}$ and $\mathrm{p} 67^{\text {phox }}$ at the phagosome membrane. These data suggested that cytochrome $\mathrm{b}_{558}$, non-functional in X-linked CGD, was required for more stable association of these cytosolic components with the phagocyte membrane. Immunofluorescence microscopy was used to show that $\mathrm{gp} 91^{\text {phox }}$ and cytosolic phospholipase A co-localize to the plasma membrane in stimulated PLB-985 cells (a neutrophil surrogate) and that in the absence of gp $91^{\text {phox }}$ phospholipase A does not translocate to the plasma membrane (Shmelzer et al. 2003). The movement of gp91 $1^{\text {phox }}$ in PMA stimulated neutrophils has been described with a set of monoclonal antibodies using immunofluorescence microscopy; one of these antibodies appeared to bind preferentially to the active form of cytochrome $b_{558}$ (Campion et al. 2007). Biochemical and immunofluorescence microscopy experiments were used to study the interactions of $\mathrm{p} 47^{\text {phox }}$ and interleukin-1 receptor-associated kinase-4 (IRAK-4) in neutrophils treated with lipopolysaccharide (LPS) (Pacquelet et al. 2007). The authors report co-localization of $\mathrm{p} 47^{\text {phox }}$ and IRAK-4 at sites near the plasma membrane in LPS stimulated neutrophils. Comparison of the sub-cellular 
localization of cytochrome $b$ in neutrophils and macrophages has been carried out using immunofluorescence microscopy. Resting neutrophils showed a primarily intracellular granular labeling pattern while macrophages did not display an intracellular labeling pattern but instead showed a cell surface pattern (Johansson et al. 1995). While not a component of the NADPH oxidase, myeloperoxidase is important in the formation of downstream ROS and for participating in microbicidal activity of neutrophils. Fluorescence microscopy and flow cytochemistry have been used to analyze binding of quantum dots conjugated with anti-myeloperoxidase (Hoshino et al. 2007). The Hoshino study reports that these quantum dots bind neutrophils stimulated with proinflammatory cytokines but not control cells.

Immunolocalization of components of the NADPH has also been carried out at the electron microscope level. Neutrophils that were cryofixed and prepared by molecular distillation drying were used in conjunction with antibodies to components of the cytochrome $b_{558}$; it was found that $\sim 20 \%$ of the immunolabel was associated with the plasma membrane with the remainder associated with cytoplasmic granules (Jesaitis et al. 1990). When ultrathin cryosections were used as the labeling substrate for a monoclonal antibody to the $22 \mathrm{kD}$ component of cytochrome $b_{558}$, there was little labeling associated with the plasma membrane with the label being primarily associated with the specific granules (Ginsel et al. 1990). In a subsequent immunoelectron microscopy study, cytochrome $b_{558}$ co-localized to a significant extent with albumin (Calafat et al. 1993). Albumin was previously shown to be a marker for the matrix of the secretory vesicle of neutrophils (Borregaard et al. 1992). This secretory vesicle is the same structure as the alkaline phosphatase-positive vesicle we described using enzyme cytochemistry (Kobayashi and Robinson 1991; Robinson et al. 1999). Cytochrome $b_{558}$ has been reported as a component of the specific granule, the gelatinase granule, and secretory vesicles of the human neutrophil (reviewed in Borregaard and Cowland 1997). The bacterium Anaplasma phagocytophilum invades neutrophils but appears to repress the respiratory burst. Immunoelectron microscopy showed that both subunits of cytochrome $b_{558}$ were significantly reduced in phagosomes containing A. phagocytophilum when compared to E. coli containing phagosomes and thus could be part of the explanation for the reduced respiratory burst (IJdo and Mueller 2004). Combined immunoelectron and immunofluorescence microscopy of neutrophils infected with A. phagocytophilum also demonstrated a low association of cytochrome $\mathrm{b}_{558}$ subunits with phagosomes containing A. phagocytophilum (Carlyon et al. 2004). These two studies with $A$. phagocytophilum illustrate the importance of immunolocalization in understanding the interaction of particular microbes and the neutrophil phagosome.

Immunolocalization experiments and particularly double or triple localization preparations can be very valuable since low affinity interactions that may be detected by immunolocalization techniques may not survive the harsher conditions associated with cell-fractionation studies. For example, as noted above, transient recruitment of $\mathrm{p} 47^{\text {phox }}$ and $\mathrm{p} 67^{\text {phox }}$ to phagosomes in neutrophils from X-linked CGD was reported (Allen et al. 1999); cell fractionation and cell-free activation systems from these cells did not show translocation of these components (Heyworth et al. 1991).

\section{Fluorescence-based localization of ROS}

The detection of ROS by fluorescence microscopy is an attractive option since it permits evaluation of single-living phagocytes. Endogenous autofluorescence associated with NADPH and NADH can be monitored and a change in the distribution of NAD $(\mathrm{P}) \mathrm{H}$ at phagosomes has been observed (Liang and Petty 1992). It is noteworthy that polarized substratum-attached neutrophils produce bursts of $\mathrm{O}_{2}^{-}$ production (determined using an exogenous fluorescent probe for ROS) that correlated with waves of $\mathrm{NAD}(\mathrm{P}) \mathrm{H}$ [determined by monitoring the autofluorescence of $\mathrm{NAD}(\mathrm{P}) \mathrm{H}]$ that traveled from the rear to the front of crawling cells (Kindzelskii and Petty 2002). In this case, cells were attached to quartz microscope slides. Production of $\mathrm{O}_{2}^{-}$occurred in control cells as well as in cells stimulated with a chemotactic peptide. The difference between the $\mathrm{NAD}(\mathrm{P}) \mathrm{H}$ wave and the release of $\mathrm{O}_{2}^{-}$in the two conditions was the periodicity; it was $\sim 22 \mathrm{~s}$ in the absence of the chemotactic peptide and $\sim 11 \mathrm{~s}$ in its presence (Kindzelskii and Petty 2002). It has long been known that in standard biochemical assays for monitoring $\mathrm{O}_{2}^{-}$production in populations of cells in suspension, that these cells are quiescent (see Fig. 1). How are these two observations to be reconciled? In the case of crawling neutrophils, they have undergone a dramatic shape change. On the other hand, neutrophils assayed in suspension have essentially the same rounded shape that they have in the bloodstream. However, when intact neutrophils, in suspension, are challenged with a stimulus (e.g., phagocytizable particles, phorbol myristate acetate, the chemotactic peptide $f$-Met-Leu-Phe, arachidonic acid, or retinoids) they too undergo changes in shape and reorganization of intracellular compartments (e.g., Badwey et al. 1984; Robinson et al. 1987; Kobayashi and Robinson 1991). The degree to which shape change itself modulates the phagocyte NADPH oxidase is not clear. Nathan (1987) has shown that tumor necrosis factors did not induce production of $\mathrm{H}_{2} \mathrm{O}_{2}$ in neutrophils in suspension but when 
these cells were attached to plastic surfaces coated with proteins (e.g., serum, fibronectin), tumor necrosis factors induced massive release of ROS. It was also observed in that study that neutrophils attached to surfaces in the absence of tumor necrosis factors also produced low levels of ROS. Another study of adherent neutrophils also found low levels of ROS release in the absence of additional stimuli (Suchard and Boxer 1994). It is interesting to note that rabbit synovial fibroblasts that had undergone integrinmediated cell shape change had activated Rac1 which was correlated with the generation of ROS by these cells (Kheradmand et al. 1998). As already noted above, Rac is a component of the assembled NADPH oxidase. Taking all of these factors into account, studies directed toward understanding, in a detailed manner, how shape change itself plays a role in generation of ROS and how shape change modulates ROS production in response to stimulation in phagocytic leukocytes seem in order.

Exogenous fluorescence probes used for monitoring ROS production have been reviewed (Gomes et al. 2005). Exogenous fluorescent probes have been used in several studies of phagocytic leukocytes. The utility and the limitations of current exogenous fluorescent probes for use with phagocytes has been reviewed (Yeung et al. 2005). Important considerations for use of the exogenous fluorescent probes, such as dihydroethidine and dihydrorhdamine 123 include mode of entry into cells and the retention of the fluorescent product at the site of ROS generation as well as the linearity of the response. A few examples of the use of exogenous fluorescence probes with neutrophils will be presented. Kobayashi et al. (2000) have used fluorescent probes for ROS detection [succinimidyl ester of dichlorodihydrofluorescein diacetate $\left(\mathrm{H}_{2}\right.$ DCFDA $\left.)\right]$ and endocytosis [TRITC-dextran] to monitor intracellular trafficking in phorbol myristate acetate-activated neutrophils. They found intracellular sites of ROS production and a complex pattern of the interaction of the ROS-positive compartments and endocytic vesicles. A reduction in $\mathrm{H}_{2}$ DCFDA was noted in the presence of fungal gliotoxin (Li et al. 2004). Streptolysin- $O$ permeabilized neutrophils were tested for production of ROS using $\mathrm{H}_{2}$ DCFDA. In this study, the ROS-induced fluorescence was monitored by flow cytometry and fluorescence microscopy (Brown et al. 2003). It was found that fluorescence was associated with intracellular structures with a granule-like labeling pattern in the permeabilized neutrophils.

An alternative strategy to applying the fluorescent probes directly to cells consists of covalent attachment of the fluorescent probe to phagocytizable particles. In this way, the ROS-induced changes in fluorescence will be restricted to the phagosome (Yeung et al. 2005). These same authors discuss the potential of using ROS-sensitive fluorescent proteins to monitor ROS production. These proteins could be expressed in phagocytic cells, in some cases, or in the target microorganism. This is an attractive prospect, however, the harsh conditions encountered in the phagosome should be taken into account in the design of environmentally-sensitive fluorescent proteins. Expression of fluorescent proteins in primary phagocytes, such as human neutrophils, is problematic so the use of microorganisms expressing the ROS-sensitive fluorescent protein as targets for phagocytosis would be preferable in this instance.

Fluorescence microscopy has been used in conjunction with a micromanipulator in order to move phagocytic targets to human neutrophils, thus allowing the study of changes in cytosolic $\mathrm{Ca}^{2+}$ and the respiratory burst associated with a single phagocytic event at a defined site in individual cells (Dewitt et al. 2003). The fluorescent probes Fura- 2 and dichlorodihydrofluorescein were used to monitor changes in cytosolic $\mathrm{Ca}^{2+}$ and production of ROS, respectively. Two $\mathrm{Ca}^{2+}$ peaks were observed to be associated with phagocytosis but only the second peak correlated with initiation of the respiratory burst.

An enzyme cytochemical experiment is shown to illustrate the dramatic nature of the morphological alterations neutrophils can display during activation. Cytochalasin B, a compound that disrupts filamentous actin in cells, has been widely used in conjunction with stimuli such as $f$ Met-Leu-Phe to enhance the release of ROS and the exocytosis of intracellular granules (e.g., Zurier et al. 1973; Honeycutt and Niedel 1986; Mukherjee et al. 1994). It has also been shown that cytochalasin B reduces the cortical tension and cytoplasmic viscosity in neutrophils (Tsai et al. 1994). We have studied the effects of cytochalasin B and $f$-Met-Leu-Phe stimulation on the morphology of human neutrophils. Cerium-based cytochemistry for the detection of alkaline phosphatase has been used in conjunction with "thick section" electron microscopy. In resting cells, in suspension, the alkaline phosphatase is present in rodshaped granules that can be detected by this cytochemical method only if the cells are permeabilized (Fig. 7). Following stimulation, these cells undergo a dramatic alteration in their organization. The cells display an elaborate system of tubular structures that are positive for alkaline phosphatase. Moreover, the cytochemical reactivity does not require cell permeabilization showing that the tubular structures are in continuity with the extracellular medium (Fig. 7). The use of "thick sections" in electron microcopy enables the appreciation of how dramatic the alterations are when neutrophils are stimulated with cytochalasin B and $f$-Met-Leu-Phe. The full extent of these changes were not observed either with conventional thin section electron microscopy or with light microscopy (not shown). These results indicate dramatic modifications in cell shape and organization that neutrophils are capable of performing. 

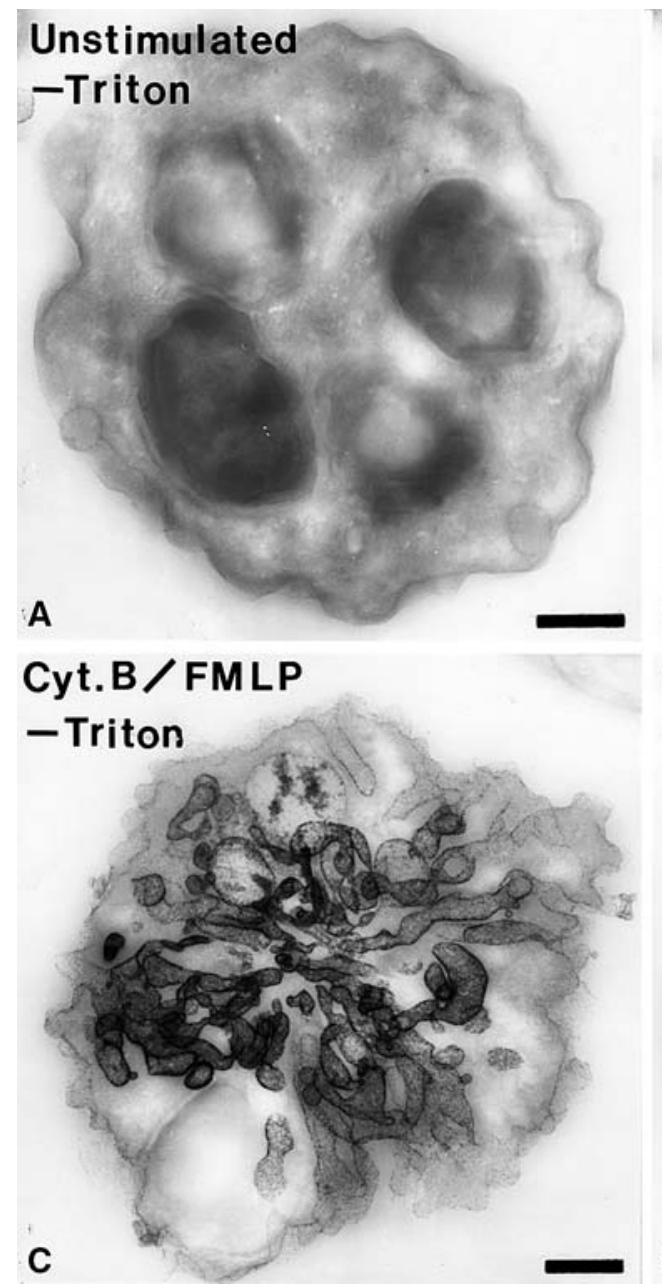

Fig. 7 Electron micrographs of thick sections $(0.35 \mu \mathrm{m}$ thickness $)$ of human neutrophils incubated for the cytochemical detection of alkaline phosphatase. a An unstimulated cell that was incubated for the detection of alkaline phosphatase activity in the absence of cell permeabilization with Triton X-100. Note that there is no reaction in the absence of permeabilization. $\mathbf{b}$ A cell that was incubated for the detection of alkaline phosphatase activity following cell permeabilization. In this case, numerous small rod-shaped organelles containing reaction product are evident. c A cell stimulated with $f$-Met-Leu-Phe (FMLP) and cytochalasin B (Cyt.B) that was incubated for the detection of alkaline phosphatase activity in the absence of cell-

Biophysical methods for study of the phagocyte NADPH oxidase

A chemiluminesence signal was detected during phagocytosis and was thought to be associated ${ }^{1} \mathrm{O}_{2}$ generation (Allen et al. 1972). Luminol was incorporated into these studies later to enhance the chemiluminesence signal (Allen and Loose 1976). Subsequently, real-time visualization of chemiluminescence associated with the respiratory burst was reported in a series of studies (Suematsu et al. 1987, 1989; Suematsu and Tsuchiya 1991). For example, rabbit neutrophils were used to study

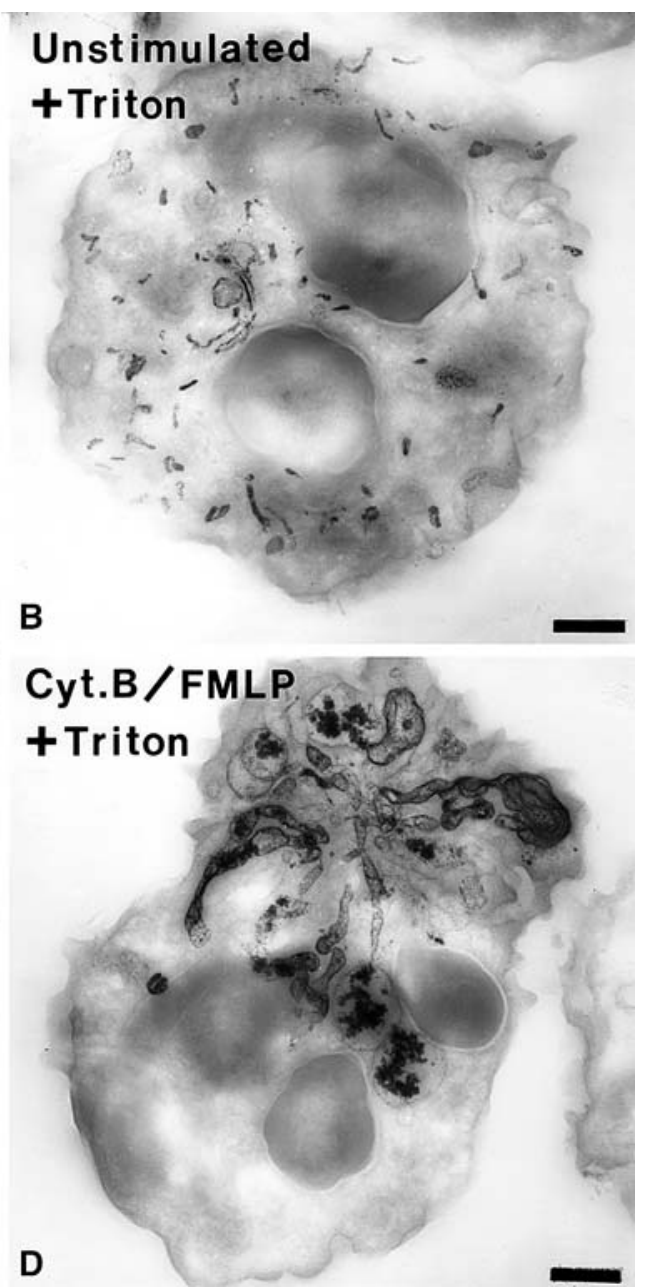

permeabilization. Note the dramatic rearrangement of the alkaline phosphatase compartments into elaborate tubular structures. These tubular structures appear to be in continuity with the extracellular space since permeabilization was not required to detect the enzyme activity. d A cell stimulated with $f$-Met-Leu-Phe (FMLP) and cytochalasin B (Cyt.B) that was incubated for the detection of alkaline phosphatase activity in the presence of cell permeabilization. This cell has a appearance similar to the cell treated in the same manner but without permeabilization. The cytochemical reaction was carried out as we have described previously (Kobayashi and Robinson 1991). Bars: $1 \mu \mathrm{m}$

exocytosis associated with formation of the phagosome in the presence of luminol (Suzaki et al. 1997). These studies required the use of a very sensitive photon-counting camera. Most of the recorded photons were in the vicinity of particles in the phagosomes. It has been proposed that chemiluminesence has advantages for imaging ROS generation in living cells when compared to fluorescence microscopy (Suematsu and Tsuchiya 1991). The suggested advantages are: (1) since the light is derived from the chemical reaction itself (i.e., chemiluminescence), excitation illumination is not required (excitation illumination may alter structure and function in living cells); (2) 
photobleaching does not occur; and (3) generation of ROS may be dissected further with specific chemilumigenic probes.

The above arguments notwithstanding, fluorescence microscopy in its various forms has been very important in cell biological studies, including those with phagocytic leukocytes. This is particularly so for live-cell imaging of stimulated leukocytes. Imaging procedures to monitor the endogenous autofluorescence signal from $\mathrm{NAD}(\mathrm{P}) \mathrm{H}$ during activation of the NADPH oxidase have been developed (Liang and Petty 1992). This procedure, when coupled with monitoring ROS generation by fluorescence microscopy, has provided intriguing data on metabolic waves in these cells and was discussed in an earlier section of this review (Kindzelskii and Petty 2002). Other oscillations, ranging from structural to biochemical, have been observed in neutrophils (reviewed in Petty 2001). Also as already noted, this same group used Soret band (absorption contrast) transmitted light to monitor changes in hemoglobin in phagocytosed erythrocytes (Petty et al. 1992).

Using high-speed fluorescence imaging (shutter speeds $\sim 100 \mathrm{~ns}$ ), it was possible to make "stop action movies" of signaling events such as calcium waves in neutrophils that had phagocytosed (Petty 2006). In this case, a calcium wave moves around the periphery of the cell and then jumps to the phagosome when it moves nearby. Rapid image acquisition methodology enabled these observations and should continue to provide new insights into cellular behavior in future work.

Other advanced imaging modalities have been employed for studying the phagocyte NADPH oxidase (reviewed in Van Manen et al. 2006). The distribution of cytochrome $\mathrm{b}_{558}$ has been imaged in resting and phagocytosing neutrophils at the single cell level by confocal resonance Raman microscopy (van Manen et al. 2003). In this case, Raman spectroscopy was used to visualize the cytochrome $\mathrm{b}_{558}$ directly rather than with a labeling procedure as in immunocytochemistry. While the cytochrome $b_{558}$ accumulates in the region of ingested particles, the spatial resolution was rather low and thus does not provide definitive localization. The authors noted that individual specific granules were not resolved using this imaging modality. Refinements in this instrumentation may improve spatial resolution. The immunofluorescence localization of gp91 ${ }^{\text {phox }}$ in hematopoietic stem cells mobilized by granulocyte-colony stimulating factor was determined by near field scanning optical microscopy (NSOM) (Frassanito et al. 2008). With NSOM imaging, they report the presence of "specialized clusters" and also that "protein domains" in the 300-600 nm size range could be detected. The precise nature of these small protein domains remains to be determined.
The use of cell lines that display certain properties of primary neutrophils have advantages over freshly isolated neutrophils for some studies. The cultured cells (e.g., PLB985 and HL-60 cells) can be manipulated in ways that are not readily applicable to primary neutrophils. For example, they can be transfected to express components of the NADPH oxidase that are tagged with fluorescent proteins such that these components can be monitored in living cells under various conditions with real-time fluorescence microscopy. An analysis of this expanding area is beyond the scope of this review; however, some examples are cited to illustrate the potential for these types of experiments. Fluorescence fusion proteins have been used to study the interaction of $\mathrm{p} 67^{\text {phox }}$ and Rac2 with the phagosome and the role of gp91 ${ }^{\text {phox }}$ in these interactions (Van Bruggen et al. 2004). A fluorescent fusion protein form of $440^{\text {phox }}$ was used to monitor the association of $\mathrm{p} 40^{\text {phox }}$ with phagosomes in cultured cells (Suh et al. 2006). The ability to express fluorescent forms of components of the NADPH oxidase opens up the possibility of applying advanced optical techniques for the study of the NADPH oxidase in living cells.

\section{Other considerations}

There is some controversy as to whether intracellular site of NADPH oxidase activity, not associated with phagosomes or the plasma membrane, normally exists. This is an important point in understanding the regulation of the oxidase and generation of ROS. Therefore, it is important to pay close attention to details of the methodology employed in the various studies that have addressed this point. It should be noted that biochemical assays of production of ROS or the consumption of oxygen in activated neutrophils are typically done with cells in suspension (e.g., Robinson et al. 1984; Dahlgren et al. 2007). Additionally, cell fractionation studies used to track the movement of oxidase components using biochemical assays have neutrophils in suspension as the starting material (reviewed in Nauseef 2004). To further complicate matters, it has been reported that standard centrifugation methods used to isolate neutrophils from blood led to the surface expression of molecules that were not detected at the surface of neutrophils in whole blood (Kuijpers et al. 1991). However, most immunocytochemical studies as well as live cell microscopy studies where ROS production is localized occur in cells attached to a substratum (e.g., cover slips, microscope slides, or plastic dishes that may also be coated with a variety of proteins) (e.g., DeLeo et al. 1999; Kindzelskii and Petty 2002). As we have already noted, it has been shown that attachment of neutrophils (and other cells) to surfaces alters their shape; in addition, attachment can modulate their activity with regard to ROS production (e.g., Nathan 1987: Suchard and Boxer 
1994; Kheradmand et al. 1998; Kindzelskii and Petty 2002). Indeed, oscillations in the respiratory burst have been correlated with fluctuations in neutrophil cell shape (Wymann et al. 1989). Petty and colleagues (Petty and Kindzelskii 2000; Kindzelskii and Petty 2002; Petty 2004, 2006) have advocated the use of high-speed imaging to study metabolic waves and cellular signaling in living neutrophils. Neutrophils were monitored during the process of cell adhesion to a substratum and it was shown that there were waves of $\mathrm{NAD}(\mathrm{P}) \mathrm{H}$ autofluorescence and cytosolic $\mathrm{pH}$ changes associated with attachment (Petty and Kindzelskii 2000). They did not monitor whether ROS production occurred during attachment in that study. However, in polarized neutrophils (crawling cells) NAD $(\mathrm{P}) \mathrm{H}$ waves were associated with production of ROS (Kindzelskii and Petty 2002). These authors stated: "We have previously noted the presence of longitudinal $\mathrm{NAD}(\mathrm{P}) \mathrm{H}$ waves in elongated neutrophils (Petty et al. 2000). Thus, cell shape (spherical vs. elongated) correlates with the dissipative metabolic patterns observed (circular vs. longitudinal)" (Petty and Kindzelskii 2000). These observations emphasize further the need to compare cells activated in suspension and those activated attached to a surface and to study the role of cell shape in neutrophil function.

In cytochemical preparations carried out with neutrophils in suspension, intracellular sites of ROS production have been observed (Kobayashi et al. 1998; Brown et al. 2003). We have shown, as have others, that the intracellular trafficking of membrane-bounded compartments in activated neutrophils can be very dramatic and complex (Kobayashi and Robinson, 1991; Robinson et al. 1999). This point is illustrated further herein (see Fig. 7). Therefore caution should be used when comparing neutrophils (and other cells as well) activated in suspension to those activated when attached to a substratum. Membrane trafficking events occurring with cells in suspension may not be exactly replicated with attached cells and vice versa. It would be useful for this issue to be addressed in a formal manner such that the intracellular trafficking patterns for membrane compartments of individual neutrophils activated in suspension or when attached to a substratum could be determined and compared.

\section{Reactive oxygen species in other cell types}

While this review has focused narrowly on phagocytic leukocytes and neutrophils in particular, it must be mentioned that ROS have assumed considerable importance beyond phagocytes. Indeed, ROS production is wide spread throughout the animal and plant kingdoms. The literature on this topic has grown considerably over the past 10 years or so and illustrates the pervasiveness of ROS production in biological systems and the importance of ROS in various biological functions. A review of this area, no matter how cursory, is well beyond the scope of this paper. However, there are numerous excellent review articles available on these topics (e.g., Geiszt and Leto 2004; Lambeth 2004; Terada 2006; Bedard and Krause 2007; Bedard et al. 2007; Lambeth 2007; Brandes and Schröder 2008).

Acknowledgments The author is indebted to Drs. John A. Badwey, his post doctoral colleague, and Morris J. Karnovsky, his post doctoral mentor, for many fruitful discussions about neutrophils and macrophages and their biochemical and cell biological properties. The late Dr. Manfred L. Karnovsky also added greatly to our discussions. I am also grateful to Dr. Richard T. Briggs for generously sharing his knowledge of neutrophils and enzyme cytochemistry when I was new to phagocyte biology. All of these interactions began at Harvard Medical School. At Ohio State University, I was privileged to begin collaborations with Drs. Toshihiro Kobayashi and Toshihiro Takizawa that have continued after they returned to Japan. Dr. Harumichi Seguchi has also contributed to our understanding of neutrophils through the use of cytochemistry. The bacterial minicells shown in Fig. 4 were generously supplied by Dr. Bernard M. Babior. I also wish to thank my current colleague Dr. William E. Ackerman IV for assistance in preparing Fig. 1.

\section{References}

Abo A, Webb MR, Grogan A, Segal AW (1994) Activation of NADPH oxidase involves the dissociation of $\mathrm{p} 21^{\text {rac }}$ from its inhibitory GDP/GTP exchange protein (rhoGDI) followed by its translocation to the plasma membrane. Biochem J 298:585-591

Allen L-AH, DeLeo FR, Gallois A, Toyoshima S, Suzuki K, Nauseef WM (1999) Transient association of the nicotinamide adenine dinucleotide phosphate oxidase subunits $\mathrm{p} 47^{\text {phox }}$ and $\mathrm{p} 67^{\text {phox }}$ with phagosomes in neutrophils from patients with X-linked chronic granulomatous disease. Blood 93:3521-3530

Allen RC, Loose LD (1976) Phagocytic activation of a luminoldependent chemiluminescence in rabbit alveolar and peritoneal macrophages. Biochem Biophys Res Commun 69:245-252

Allen RC, Stjernholm RL, Steele RH (1972) Evidence for the generation of an electronic excitation state(s) in human polymorphonuclear leukocytes and its participation in bactericidal activity. Biochem Biophys Res Commun 47:679-684

Ambruso DR, Cusack N, Thurman G (2004) NADPH oxidase activity of neutrophil specific granules: requirements for cytodolic components and evidence of assembly during cell activation. Mol Genet Metab 81:313-321

Angermüller S, Fahimi D (1988) Light microscopic visualization of reaction product of cerium used for localization of peroxisomal oxidases. J Histochem Cytochem 36:23-28

Auclair C, Voisin E (1985) Nitroblue tetrazolium reduction. In: Greenwald RA (ed) Handbook of methods for oxygen radical research. CRC Press, Boca Raton, pp 123-132

Babbs CF (1994) Histochemical methods for localization of endothelial superoxide and hydrogen peroxide generation in perfused organs. Meth Enzymol 233:619-630

Babbs CF, Cregor MD, Turek JJ, Badylak SF (1991a) Endothelial superoxide production in buffer perfused rat lungs, demonstration by a new histochemical technique. Lab Invest 65:484-496

Babbs CF, Cregor MD, Turek JJ, Badylak SF (1991b) Endothelial superoxide production in the isolated rat heart during reperfusion after ischemia. A histochemical study. Am J Pathol 139:1069-1080 
Babior BM (2004) NADPH oxidase. Curr Opin Immunol 16:42-47

Babior BM, Lambeth JD, Nauseef WM (2002) The neutrophil NADPH oxidase. Arch Biochem Biophys 397:342-344

Babior BM, Kipnes RS, Curnutte JT (1973) Biological defense mechanisms. The production of superoxide, a potential, a potential bactericidal agent. J Clin Invest 52:741-744

Badwey JA, Curnutte JT, Robinson JM, Lazdins JK, Briggs RT, Karnovsky MJ, Karnovsky ML (1980) Comparitive aspects of the oxidative metabolism of neutrophils from human blood and guinea pig peritonea: magnitude of the respiratory burst, dependence upon stimulatory agents, and localization of the oxidases. J Cell Physiol 105:541-551

Badwey JA, Curnutte JT, Robinson JM, Berde CB, Karnovsky MJ, Karnovsky ML (1984) Effects of free fatty acids on release of superoxide and on change of shape by human neutrophils. J Biol Chem 259:7870-7877

Baldridge CW, Gerard RW (1933) The extra respiration of phagocytosis. Am J Physiol 103:235-236

Beckman JS, Beckman TW, Chen J, Marshall PA, Freeman BS (1990) Apparent hydroxyl radical production by peroxynitrite: implications for endothelial injury from nitric oxide and superoxide. Proc Natl Acad Sci USA 87:1620-1624

Bedard K, Krause JH (2007) The NOX family of ROS-generating NADPH oxidases: physiology aand pathophysiology. Physiol Rev 87:245-313

Bedard K, Lardy B, Krause KH (2007) MOX family NADPH oxidases: not just in mammals. Biochimie 89:1107-1112

Bokoch GM, Diebold BA (2002) Current molecular models for NADPH oxidase regulation by Rac GTPase. Blood 100:2692-2696

Bokoch GM, Knaus UG (2003) NADPH oxidases: not just for leukocytes anymore!. Trends Biochem Sci 28:502-508

Bokoch GM, Bohl BP, Chuang T-H (1994) Guanine nucleotide exchange regulates membrane translocation of Rac/Rho GTPbinding proteins. J Biol Chem 269:31674-31679

Borregaard N, Cowland JB (1997) Granules of the human neutrophilic polymorphonuclear leukocyte. Blood 89:3503-3521

Borregaard N, Moller LJ, Springer TA (1987) Chemoattractantregulated mobilization of a novel intracellular compartment in human neutrophils. Science 237:1204-1206

Borregaard N, Kjeldsen L, Rygaard K, Bastholm L, Nielsen MH, Sengeløv H, Bjerrum OW, Johnsen AH (1992) Stimulusdependent secretion of plasma proteins from human neutrophils. J Clin Invest 90:86-96

Botelho RJ, Trapper H, Furuya W, Mojdami D, Grinstein S (2002) $\mathrm{F} c \gamma \mathrm{R}$-mediated phagocytosis stimulates localized pinocytosis in human neutrophils. J Immunol 169:4423-4429

Brandes RP, Schröder K (2008) Composition and function of vascular nicotinamide adenine dinucleotide phosphate oxidases. Trends Cardiovasc Med 18:15-19

Briggs RT, Karnovsky ML, Karnovsky MJ (1975a) Cytochemical demonstration of hydrogen peroxide in polymorphonuclear phagosomes. J Cell Biol 64:254-260

Briggs RT, Drath DB, Karnovsky ML, Karnovsky MJ (1975b) Localization of NADH oxidaseon the surface of human polymorphonuclear leukocytes by a new cytochemical method. J Cell Biol 67:566-586

Briggs RT, Robinson JM, Karnovsky ML, Karnovsky MJ (1986) Superoxide production by polymorphonuclear leukocytes. A cytochemical approach. Histochemistry 84:371-378

Bromberg Y, Pick E (1984) Unsaturated fatty acids stimulate NADPH-dependent syperoxide production by cell-free system derived from macrophages. Cell Immunol 88:213-221

Brown GE, Stewart MQ, Liu H, Ha V-L, Yaffe MB (2003) A novel assay system implicates Ptdlns(3, 4)P2, Ptdlns(3)P, and PKC $\delta$ in intracellular production of oxygen species by the NADPH oxidase. Mol Cell 11:35-47

Calafat J, Kuijpers TW, Janssen H, Borregaard N, Verhoeven AJ, Roos D (1993) Evidence for small intracellular vesicles in human blood phagocytes containing cytochrome $b_{558}$ and the adhesion molecule CD11b/CD18. Blood 81:3122-3129

Campion Y, Paclet M-H, Jesaitis AJ, Marques B, Grichine A, Berthier S, Lenormand J-L, Lardy B, Stasia M-J, Morel F (2007) New insights into the membrane topology of the phagocyte NADPH oxidase: Characterization of an anti-gp91 phox conformational monoclonal antibody. Biochimie 89:1145-1158

Carlyon JA, Latif DA, Pypaet M, Lacy P, Fikrig E (2004) Anaplasma phagocytophilum utilizes multiple host evasion mechanisms to thwart NADPH oxidase-mediated killing during neutrophil infection. Infect Immun 72:4772-4783

Champelovier P, Laporte F, Verhoeven AJ, Hilarius P, Klein AD, Revol C, Seigneurin D, Kolodie L (1993) Absence of both subunits of cytochrome $\mathrm{b}_{558}$ in the UM384 cell line relative to the inability to generate superoxide anions. Exp Hematol 21:885-892

Corey EJ, Mehrotra MM, Khan AU (1987) Antiarthritic gold compounds effectively quench electronically excited singlet oxygen. Science 236:68-69

Cross AR, Segal AW (2004) The NADPH oxidase of professional phagocytes-prototype of the NOX electron transport chain systems. Biochim BiophysActa 1657:1-22

Curnutte JT (1985) Activation of human neutrophil nicotinamide adenine dinucleotide phosphate, reduced (triphosphopyridine nucleotide, reduced) oxidase by arachidonic acid in a cell-free system. J Clin Invest 75:1740-1743

Curnutte JT, Whitten DM, Babior BM (1974) Defective superoxide production by granulocytes from patients with chronic granulomatous disease. N Engl J Med 290:593-597

Dagher M-C, Pick E (2007) Opening the black box: lessons from cellfree systems on the phagocyte NADPH-oxidase. Biochimie 89:1123-1132

Dahlgren C, Karksson A, Bylund J (2007) Measurement of respiratory burst products generated by professional phagocytes. Methods Mol Biol 412:349-363

Davies EV, Hallett MB, Campbell AK (1991) Localized superoxide release by neutrophils can be provoked by a cytosolic calcium cloud. Immunology 73:228-234

DeLeo FR, Allen L-AH, Apicella M, Nauseef WM (1999) NADPH oxidase activation and assembly during phagocytosis. J Immunol 163:6732-6740

Dewitt S, Laffafian I, Hallett MB (2003) Phagosomal oxidase activity during $\beta 2$ integrin (CR3)-mediated phagocytosis by neutrophils is triggered by a non-restrictive $\mathrm{Ca}^{2+}$ signal: $\mathrm{Ca}^{2+}$ controls time not space. J Cell Sci 116:2857-2865

DiGregorio KA, Cilento EV, Lantz RC (1991) Heterogeneity in superoxide production as measured by nitroblue tetrazolium reduction from individual PAM. Am J Physiol 260:L464-L470

Dinauer MC, Orkin SH, Brown R, Jesaitis AJ, Parkos CA (1987) The glycoprotein encoded by the $\mathrm{X}$-linked chronic granulomatous disease locus is a component of the neutrophil cytochrome $b$ complex. Nature 327:717-720

Fox HB, DeTogni P, McMahon G, Levy SB, Robinson JM, Karnovsky MJ, Babior BM (1987) Fate of the DNA in plasmid-containing E. coli minicells ingested by human neutrophils. Blood 69:1394-1400

Frassanito MC, Piccoli C, Capozzi V, Boffoli D, Tabilio A, Capitanio N (2008) Topological organization of NADPH-oxidase in haematopoietic stem cell membrane: preliminary study by fluorescence near-field optical microscopy. J Microsc 229:517-524 
Geiszt M, Leto TL (2004) The Nox family of NAD(P)H oxidases: host defense and beyond. J Biol Chem 279:51715-51718

Ginsel LA, Onderwater JJM, Fransen JAM, Verhoeven AJ, Roos D (1990) Localization of the low- $M_{r}$ subunit of cytochrome $b_{558}$ in human blood phagocytes by immunoelectron microscopy. Blood 76:2105-2116

Gomes A, Fernandes E, Lima JLFC (2005) Fluorescene probes used for detection of reactive oxygen species. J Biochem Biophys Methods 65:45-80

Griffiths G (2004) On phagosome individuality and membrane signaling networks. Trends Cell Biol 14:343-351

Groemping Y, Rittinger K (2005) Activation and assembly of the NADPH oxidase: a structural perspective. Biochem J 386:401-416

Halbhuber KJ, Gossrau R, Moller U, Hulstaert CE, Zimmerman N (1988) The cerium perhydroxide-diaminobenzidine $\left(\mathrm{Ce}-\mathrm{H}_{2} \mathrm{O}_{2}\right.$ $\mathrm{DAB}$ ) procedure. New methods for light microscopic phosphatase histochemistry and immunocytochemistry. Histochemistry 90:289-297

Halbhuber KJ, Hulstaert CE, Feuerstein H, Zimmermann N (1994) Cerium as capturing agent in phosphatase and oxidase histochemistry. Theoretical background and applications. Prog Histochem Cytochem 28:1-120

Harrison JE, Schultz J (1976) Studies on the chlorinating activity of myeloperoxidase. J Biol Chem 251:1371-1374

Hartfield PJ, Robinson JM (1990) Fluoride-mediated activation of the respiratory burst in electropermeabilized neutrophils. Biochim Biophys Acta 1054:176-180

Heyneman RA, Vercauteren RE (1984) Activation of an NADPHdependent oxidase from horse polymorphonuclear leukocytes in a cell-free system. J Leukoc Biol 36:751-759

Heyworth PG, Curnutte JT, Nauseef WM, Volpp BD, Pearson DW, Rosen H, Clark RA (1991) Neutrophil nicotinamide adenine dinucleotide phosphate oxidase assembly: translocation of $\mathrm{p}$ 47 phox and p-67phox requires interaction between $\mathrm{p}-47$ phox and cytochrome $b_{558}$. J Clin Invest 87:352-356

Heyworth PG, Robinson JM, Ding J, Ellis BA, Badwey JA (1997) Cofilin undergoes rapid dephosphorylation in stimulated neutrophils and translocates to ruffled membranes enriched in products of the NADPH oxidase complex. Evidence for a novel cycle of phosphorylation and dephosphorylation. Histochem Cell Biol 108:221-233

Heyworth PG, Cross AR, Curnutte JT (2003) Chronic granulomatous disease. Curr Opin Immunol 15:578-584

Honeycutt PJ, Niedel JE (1986) Cytochalasin B enhancement of the diacylglycerol response in formyl peptide-stimulated neutrophils. J Biol Chem 261:15900-15905

Hoshino A, Nagao T, Nakasuga A, Ishida-Okawara A, Suzuki K, Yasuhara M, Yamamoto K (2007) Nanocrystal quantum dotconjugated anti-myeloperoxidase antibody as the detector of activated neutrophils. IEEE Trans Nanobioscience 6:341-345

IJdo JW, Mueller AC (2004) Neutrophil NADPH oxidase is reduced at the Anaplasma phagocytophilum phagosome. Infect Immun 72:5392-5401

Iyer GYN, Islam DMF, Quastel JH (1961) Biochemical aspects of phagocytosis. Nature 192:535-541

Jesaitis AJ, Buescher ES, Harrison D, Quinn MT, Parkos CA, Livesy S, Linner J (1990) Ultrastructural localization of cytochrome b in the membranes of resting and phagocytosing human neutrophils. J Clin Invest 85:821-835

Johansson A, Jesaitis AJ, Lundqvist H, Magnusson K-R, Sjölin C, Karlsson A, Dahlgren C (1995) Different subcellular localization of cytochrome $\mathrm{b}$ and the dormant NADPH-oxidase in neutrophils and macrophages: effect on the production of reactive oxygen species during phagocytosis. Cell Immunol 161:61-71
Karlsson A, Dahlgren C (2002) Assembly and activation of the neutrophil NADPH oxidase in granule membranes. Antioxid Redox Signal 4:49-60

Karlsson A, Nixon JB, McPhail LC (2000) Phorbol myristate acetate induces neutrophil NADPH-oxidase activity by two separate signal transductionpathways: dependent or independent of phosphatidylinositol 3-kinase. J Leukoc Biol 67:396-404

Karnovsky MJ (1994) Cytochemistry and reactive oxygen species: a retrospective. Histochemistry 102:15-27

Kheradmand K, Werner E, Tremble P, Symons M, Werb Z (1998) Role of Rac1 and oxygen radicals in collagenase- 1 expression induced by cell shape change. Science 280:898-902

Kindzelskii AL, Petty HR (2002) Apparent role of traveling metabolic waves in oxidant release by living neutrophils. Proc Natl Acad Sci USA 99:9207-9212

Klebanoff SJ (1970) Myeloperoxidase: contribution to the microbicidal activity of intact leukocytes. Science 169:1095-1097

Kobayashi T, Robinson JM (1991) A novel intracellular compartment with unusual secretory properties in human neutrophils. J Cell Biol 113:743-756

Kobayashi T, Robinson JM, Seguchi H (1998) Identification of intracellular sites of superoxide production in stimulated neutrophils. J Cell Sci 111:81-91

Kobayashi T, Zinchuk VS, Okada T, Wakiguchi H, Kurashige T, Takatuji H, Seguchi H (2000) A simple approach for the analysis of intracellular movement of oxidant-producing intracellular compartments in living neutrophils. Histochem Cell Biol 113:251-257

Kreck ML, Freeman JL, Abo A, Lambeth JD (1996) Membrane association of Rac is required for high activity of the respiratory burst oxidase. Biochemistry 35:15683-15692

Kuijpers TW, Tool ATJ, Van der Schoot CE, Onderwater JJM, Roos D, Verhoeven AJ (1991) Membrane surface antigen expression in neutrophils: a reappraisal of the use of surface markers for neutrophil activation. Blood 78:1105-1111

Lambeth J (2000) Regulation of the phagocyte respiratory burst oxidase by protein interactions. J Biochem Mol Biol 33:427-439

Lambeth JD (2004) NOX enzymes and the biology of reactive oxygen. Nat Rev Immunol 4:181-189

Lambeth JD (2007) Nox enzymes, ROS, and chronic disease: an example of antagonistic pleiotrophy. Free Radic Biol Med 43:332-347

Lapouge K, Smith SJM, Walker PA, Gamblin SJ, Smerdon SJ, Rittinger K (2002) Structure of the TPR domain of $\mathrm{p} 67^{\text {phox }}$ in complex with Rac-GTP. Mol Cell 6:899-907

Li G, Kobayashi T, Tsunawaki S, Ogawa Y, Seguchi H (2004) Glitoxin-inhibits superoxide production and exocytosos of the oxidant-producing intracellular compartments in human neutrophils stimulated with phorbol myristate acetate. Acta Histochem Cytochem 37:183-189

Liang B, Petty HR (1992) Imaging neutrophil activation: analysis of the translocation and utilization of $\mathrm{NAD}(\mathrm{P}) \mathrm{H}$-associated autofluorescence during antibody-dependent target oxidation. J Cell Physiol 152:145-156

Lundqvist H, Follin P, Khalfan L, Dahlgren C (1996) Phorbol myristate acetate-induced NADPH oxidase activity in human neutrophils: only half the story has been told. J Leukoc Biol 5:270-279

Lundqvist-Gustafsson H, Bengtsson $T$ (1999) Activation of the granule pool of the NADPH oxidase accelerates apotosis in neutrophils. J Leukoc Biol 65:196-204

Malech HL, Hickstein DD (2007) Genetics, biology and clinical management of myeloid cell primary immune deficiencies: chronic granulomatous disease and leukocyte adhesion deficiency. Curr Opin Hematol 14:29-36 
Matute JD, Arias AA, Dinauer MC, Patiño PJ (2005) p40 phox: The last NADPH oxidase subunit. Blood Cells Mol Dis 35:291302

McPhail LC, Shirley PS, Clayton CC, Snyderman R (1985) Activation of the respiratory burst enzyme from human neutrophils in a cell-free system: evidence for a soluble cofactor. J Clin Invest 75:1735-1739

Mukherjee G, Quinn MT, Linner JG, Jesaitis AJ (1994) Remodeling of the plasma membrane after stimulation of neutrophils with f-Met-Leu-Phe and dihydrocytochalasin B: identification of membrane subdomains containing NADPH oxidase activity. J Leukoc Biol 55:685-694

Nathan CF (1987) Neutrophil activation on biological surfaces. Massive secretion of hydrogen peroxide in response to products of macrophages and lymphocytes. J Clin Invest 80:1550-1560

Nathan DG, Bachner RL, Weaver DK (1969) Failure of nitroblue tetrazolium in the phagocytic vacuoles in chronic granulomatous disease. J Clin Invest 48:1895-1904

Nauseef WM (2004) Assembly of the phagocyte NADPH oxidase. Histochem Cell Biol 122:277-291

Nauseef WM (2007) How human neutrophils kill and degrade microbes: an integrated view. Immunol Rev 219:88-107

Oez S, Birkmann C, Kalden JR (1993) Clonal growth of functionally normal and deficient neutrophils from the bone marrow of a patient with variant chronic granulomatous disease. Ann Hematol 66:21-25

Ohno Y-I, Hirai K-I, Kanoh T, Uchino H, Ogawa K (1982) Subcellular localization of $\mathrm{H}_{2} \mathrm{O}_{2}$ production in human neutrophils stimulated with particles and an effect of cytochalasin-B on cells. Blood 60:253-260

Okada T, Kobayashi T, Hakoi K, Seguchi H (1987) A simple method for light microscopical visualization of phospho-hydrolase activity in materials processed for cerium-based ultracytochemistry. Acta Histochem Cytochem 20:105-110

Pacquelet S, Johnson JL, Ellis BA, Brzezinska AA, Lane WS, Munafo DB, Catz SD (2007) Cross-talk between IRAK-4 and the NADPH oxidase. Biochem J 403:451-461

Parkos CA, Dinauer MC, Walker LE, Allen RA, Jesaitis AJ, Orkin SH (1988) Primary structure and unique expression of the 22kilodalton light chain of human neutrophil cytochrome b. Proc Natl Acad Sci USA 85:3319-3323

Petty HR (2001) Neutrophil oscillations. Temporal and spatiotemporal aspects of cell behavior. Immunol Rev 23:85-94

Petty HR (2004) Dynamic chemical instabilities in living cells may provide a novel route in drug development. Chembiochem 5:1359-1364

Petty HR (2006) Spatiotemporal chemical dynamics in living cells: From information trafficking to cell physiology. Biosystems $83: 217-224$

Petty HR, Kindzelskii AL (2000) High-speed imaging of stimulated metabolic target patterns in living neutrophils during adherence. J Phys Chem B 104:10962-10955

Petty HR, Liang B, Maher RJ (1992) Mapping the entry of reactive oxygen metabolites into target erythrocutes during neutrophilmediated antibody-dependent cellular cytotoxicity. J Cell Physiol 150:447-450

Petty HR, Worth RG, Kindzelskii AL (2000) Imaging sustained dissipative patterns in the metabolism of individual cells. Phys Rev Lett 84:2754-2757

Pruett SB, Loftis AY (1990) Characteristics of MTT as an indicator of viability and respiratory burst activity of human neutrophils. Int Arch Allergy Appl Immunol 92:189-192

Quinn MT, Evans T, Loetterle LR, Jesaitis AJ, Bokoch GM (1993) Translocation of Rac correlates with NADPH oxidase activitation. Evidence for equimolar translocation of oxidase components. J Biol Chem 268:20983-20987
Ramos CL, Pou S, Britigan BE, Cohen MS, Rosen GM (1992) Spin trapping evidence for myeloperoxidase-dependent hydroxyl radical formation by human neutrophils and monocytes. J Biol Chem 267:8307-8312

Robinson JM, Karnovsky MJ (1983a) Cytochemical localization of the ectoenzyme $5^{\prime}$-nucleotidase by a new cytochemical method. J Histochem Cytochem 31:1190-1196

Robinson JM, Karnovsky MJ (1983b) Ultrastructural localization of several phosphatases with cerium. J Histochem Cytochem 31:1197-1208

Robinson JM, Batten BE (1989) Detection of diaminobenzidine reactions using scanning laser confocal reflectance microscopy. J Histochem Cytochem 37:1761-1765

Robinson JM, Batten BE (1990) Localization of cerium-based reaction products by scanning laser reflectance confocal microscopy. J Histochem Cytochem 38:315-318

Robinson JM, Badwey JT (1995) The NADPH oxidase complex of phagocytic leukocytes: a biochemical and cytochemical view. Histochemistry 103:163-180

Robinson JM, Badwey JA, Karnovsky ML, Karnovsky MJ (1984) Superoxide release by neutrophils: synergistic effects of a phorbol ester and calcium ionophore. Biochem Biophys Res Commun 122:734-739

Robinson JM, Badwey JA, Karnovsky MJ, Karnovsky ML (1987) Cell surface dynamics of neutrophils stimulated with phorbol esters or retinoids. J Cell Biol 105:417-426

Robinson JM, Kobayashi T, Seguchi H, Takizawa T (1999) Evaluation of neutrophil structure and function by electron microscopy: cytochemical studies. J Immunol Methods 232:169-178

Robinson JM, Ohira T, Badwey JA (2004) Regulation of the NADPH-oxidase complex of phagocytic leukocytes. Recent insights from structural biology, molecular genetics, and microscopy. Histochem Cell Biol 122:293-304

Roos D, van Bruggen R, Meischl C (2003) Oxidative killing of microbes by neutrophils. Microbes Infect 5:1307-1315

Sbarra AJ, Karnovsky ML (1959) The biochemical basis of phagocytosis. I. Metabolic changes during the ingestion of particles by polymorphonuclear leukocytes. J Biol Chem 234:1335-1362

Segal AW, Jones OTG (1978) Novel cytochrome b system in phagocytic vacuoles from human granulocytes. Nature 276:515517

Segal BH, Leto TL, Gallin JI, Malech HL, Holland SM (2000) Genetic, biochemical, and clinical features of chronic granulomatous disease. Medicine 79:170-200

Sheppard FR, Kelher MR, Moore EE, McLaughlin NJD, Banerjee A, Silliman CC (2005) Structural organization of the neutrophil NADPH oxidase: phosphorylation and translocation during priming and activation. J Leukoc Biol 78:1025-1042

Shmelzer Z, Haddad N, Admon E, Pessach I, Leto TL, Eitan-Hazan Z, Hershfinkel M, Levy R (2003) Unique targeting of cytosolic phospholipase $\mathrm{A}_{2}$ to plasma membranes mediated by the NADPH oxidase in phagocytes. J Cell Biol 162:683-692

Steinbeck ML, Khan AU, Karnovsky MJ (1992) Intracellular singlet oxygen generation by phagocytosing neutrophils in response to particles coated with a chemical trap. J Biol Chem 267:13425-13433

Steinbeck ML, Khan AU, Appel WH Jr, Karnovsky MJ (1993) The DAB- $\mathrm{Mn}^{++}$cytochemical method revisited: validation of specificity for superoxide. J Histochem Cytochem 41:1659-1667

Suchard SJ, Boxer LA (1994) Exocytosis of a subpopulation of specific granules coincides with $\mathrm{H}_{2} \mathrm{O}_{2}$ production in adherent human neutrophils. J Immunol 152:290-300

Suematsu M, Tsuchiya M (1991) Platelet-activating factor and granulocyte-mediated oxidative stress. Strategy for in vivo oxyradical visualization. Lipids 26:1362-1368 
Suematsu M, Oshio C, Miura S, Tsuchiya M (1987) Real-time visualization of oxyradical burst from single neutrophil by using ultrasentitive video intensifier microscopy. Biochem Biophys Res Commun 149:1106-1110

Suematsu M, Kurose I, Asako H, Hiura S, Tsuchiya M (1989) In vivo visualization of oxyradical-dependent photoemission during endothelium-granulocyte interaction in microvascular beds treated with platelet-activating factor. J Biochem 106:355-360

Suh C-I, Stull ND, Li XJ, Tian W, Price MO, Grinstein S, Yaffe MB, Atkinson S, Dinauer MC (2006) The phosphoinositide-binding protein $\mathrm{p} 40^{\text {phox }}$ activates the NADPH oxidase during Fc $\gamma$ IIA receptor-induced phagocytosis. J Exp Med 203:1915-1925

Suzaki E, Kobayashi H, Kodama Y, Masujima T, Terakawa S (1997) Video-rate dynamics of exocytotic events associated with phagocytosis in neutrophils. Cell Motil Cytoskeleton 38:215228

Tarpey MM, Wink DA, Grisham MB (2004) Methods for the detection of reactive metabolites of oxygen and nitrogen: in vitro and in vivo considerations. Am J Physiol Regul Integr Comp Physiol 286:R431-R444

Terada LS (2006) Specificity in reactive oxidant signaling: think globally, act locally. J Cell Biol 174:615-623

Tsai MA, Frank RS, Waugh RE (1994) Passive mechanical behavior in human neutrophils: effects of cytochalasin B. Biophys J 66:2166-2172

Vaissiere C, Le Cabec V, Maridonneau-Parini I (1999) NADPH oxidase is functionally assembled in specific granules during activation of human neutrophils. J Leukoc Biol 65:629-634

Van Bruggen R, Anthony E, Fernandez-Borja M, Roos D (2004) Continuous translocation of Rac2 and the NADPH oxidase component $\mathrm{p} 67^{\text {phox }}$ during phagocytosis. J Biol Chen 279:90979102

Van Manen H-J, Uzunbajakava N, van Bruggen R, Roos D, Otto C (2003) Resonance Raman imaging of the NADPH oxidase subunit cytochrome $b_{558}$ in single neutrophilic granulocytes. J Am Chem Soc 125:12112-12113

Van Manen H-J, Van Bruggen R, Roos D, Otto C (2006) Single-cell optical imaging of the phagocyte NADPH oxidase. Antioxid Redox Signal 8:1509-1522

Van Noorden CJK, Fredericks WM (1993) Cerium methods for light and electron microscopal histochemistry. J Microsc 171:3-16

Vignais PV (2002) The superoxide-generating NADPH oxidase: structural aspects and activation mechanisms. Cell Mol Life Sci 59:1428-1459
Vissers MCM, Day WA, Winterborn CC (1985) Neutrophils adherent to a nonphagocytable surface (glomerular basement membrane) produce oxidants only at the site of attachment. Blood 66:161-166

Wentworth P Jr, McDunn JE, Wentworth AD, Takeuchi C, Nieva J, Jones T, Bautista C, Ruedi JM, Gutierrez A, Jada KD, Babior BM, Eschenmoser A, Lerner RA (2002) Evidence for antibodycatalyzed ozone formation in bacterial killing and inflammation. Science 298:2195-2199

Wientjes FB, Hsuan JJ, Totty NF, Segal AW (1993) p40phox, a third cytosolic component of the activation complex of the NADPH oxidase to contain src homology 3 domains. Biochem $\mathrm{J}$ 296:557-561

Wientjes FB, Panayotou G, Reeves E, Segal AW (1996) Interactions between cytosolic components of the NADPH oxidase: $\mathrm{p} 40^{\text {phox }}$ interacts with both p67 phox and p47 phox . Biochem J 317:919-924

Wymann MP, Kernen P, Deranleau DA, Baggiolini M (1989) Respiratory burst oscillations in human neutrophils and their correlation with fluctuations in apparent cell shape. J Biol Chem 264:15829-15834

Xie Q, Cho HJ, Calaycay J, Mumford RA, Swiderek KM, Lee TD, Ding A, Trosco T, Nathan C (1992) Cloning and characterization of inducible nitric oxide synthetase from mouse macrophages. Science 256:225-228

Yeung T, Touret N, Grinstein S (2005) Quantitative fluorescence microscopy to probe intracellular environments. Curr Opin Microbiol 8:350-358

Zhan S, Vazquez N, Wientjes FB, Budarf ML, Schrock E, Reid T, Green ED, Chanock SJ (1998) Genomic structure, chromosomal localization, start of transcription, and tissue expression of the p40-phox, a new component of the nicotinamide adenine dinucleotide phosphate-oxidase complex. Blood 88:2714-2721

Zimmerman N, Halbhuber KJ (1985) Light microscopical localization of enzymes by means of cerium based methods. I. Detection of acid phosphatase by a new cerium-lead technique. Acta Histochem 76:97-104

Zurier RB, Hoffstein S, Weissmann G (1973) Cytochalasin B: effects on lysosomal enzyme release from human leukocytes. Proc Natl Acad Sci USA 70:844-848 